\title{
O Vocabulário Tupinambá do Arcano del mare de Sir Robert Dudley (1661)
}

\author{
Tupinambá Vocabulary of Arcano del Mare \\ by Sir Robert Dudley (1661)
}

Nelson Papavero ${ }^{2}$

Ruth Maria Fonini Monserrat ${ }^{3}$

\section{Resumo}

Sir Robert Dudley (7 de agosto de 1574 - 6 de setembro de 1649) era filho ilegítimo de Robert Dudley, $1^{\circ}$. Conde de Leicester. Em 1594 fez uma expedição a Trinidad e Porto Rico, para apresar naves espanholas, da qual publicou um relato; compilou um vocabulário de Arawak com 69 palavras ou frases curtas. Abandonou a Inglaterra definitivamente em 1605, ficando a serviço de Fernando I (Medici), Grão-Duque da Toscana (e posteriormente também a serviço de Fernando II). Trabalhou como engenheiro e cartógrafo. Em 1608, convenceu Fernando I a enviar o navio corsário Santa Lucia Buonaventura à Guiana e ao Norte do Brasil. Para fazer essa expedição, indicou William Davies, Cirurgião-Barbeiro de Londres, que posteriormente (1614) escreveria suas memórias, incluindo suas experiências na boca do Amazonas (estas aqui transcritas e traduzidas) - o primeiro relato conhecido sobre a Amazônia do século XVII. A obra mais importante de Dudley foi o Dell'Arcano del Mare (Sobre o segredo do mar) (1646-1648, em quatro volumes). Esse impressionante e minucioso tratado de astronomia, navegação, construção naval e cartografia inclui 130 mapas, todos de sua própria criação e não copiados de outras fontes, como era costumeiro na época; reúne todos os conhecimentos náuticos desse tempo. Os mapas das costas do Brasil (aqui reproduzidos) são notavelmente detalhados e mostram os nomes das tribos indígenas. Doze anos após sua morte foi publicada a segunda edição de sua obra magna (Dudley, 1661), agora em dois volumes. Houve um grande rearranjo do texto, com a inclusão de muitas adições, ao que se diz coligidas de manuscritos deixados pelo autor. Nessa edição, no segundo volume, encontra-se um pequeno vocabulário da língua Tupinambá, com 136 vocábulos ou frases curtas, retirados sem um critério aparente da obra de Jean de Léry $(1578,1594)$, aqui apresentado facsimilarmente, transcrito, corrigido e traduzido.

Palavras-chave: Sir Robert Dudley. Arcano del Mare (1661). Vocabulário Tupinambá. Jean de Léry. William Davies. Relato sobre a foz do Amazonas (1614).

\footnotetext{
${ }^{1}$ À saudosa memória do Prof. Dr. Aryon Dall’Igna Rodrigues, mestre e queridíssimo amigo de muitos anos.

${ }^{2}$ Museu de Zoologia, Universidade de São Paulo, São Paulo, SP. Bolsista de Produtividade Científica do Conselho Nacional de Desenvolvimento Científico e Tecnológico (CNPq).

${ }^{3}$ Centro de Letras e Artes, Universidade Federal do Rio de Janeiro, Rio de Janeiro, RJ.
} 


\section{Abstract}

Sir Robert Dudley (August 7, 1574 - September 6, 1649) was an illegitimate son of Robert Dudley, First Count of Leicester. In 1594 he undertook an expedition to Trinidad and Puerto Rico, to capture Spanish ships, publishing a report about it, where he presented an Arawak vocabulary with 69 words or short sentences. Abandoning England definitely in 1605, he entered into the service of Ferdinando I (Medici), the Great-Duke of Tuscany (and afterwards also into the service of Ferdinando II). He worked as an engineer and cartographer. In 1608 he convinced Ferdinand I to send the pirate ship Santa Lucia Buonaventura to Guyana and northern Brazil. As head of that expedition he indicated William Davies, Barber-Surgeon of London, who would later (1614) publish his memoirs, including his experiences at the mouth of the Amazon River (here transcribed and translated) - the first report on the Amazons known in the 17th century. Dudley's most important work, however, was Dell'Arcano del Mare (On the secret of the sea) (1646-1648, in four volumes). This impressive and detailed treatise about astronomy, navigation, naval construction and cartography included 130 maps, all newly made by him and not copied from other sources, as was usual at that time, summing up all the nautical knowledge of the age. The maps of the Brazilian coast (herein reproduced) are remarkably detailed, showing the names of numerous Indian tribes. Twelve years after his death the second edition of his magum opus was published (Dudley, 1661), now with two volumes. A considerable rearrangement of the text was made, with the inclusion of many additions, apparently obtained from manuscripts left by the author. In this edition, in the second volume, a small vocabulary in the Tupinambá language may be found, with 136 words or short sentences, extracted, without any apparent criterion, from Jean de Léry's works $(1578,1594)$ - the vocabulary is here facsimilarly presented, transcribed, corrected and translated.

Keywords: Sir Robert Dudley. Arcano del Mare (1661). Tupinambá vocabulary. Jean de Léry. William Davies. Report on the Amazon River (1614).

Robert Dudley, $1^{\circ}$. Conde de Leicester (cf. Role 2003; Wilson 1981) (Figura 1) teve um filho, também chamado Robert (Figura 2), com sua amante Lady Douglas Sheffield, filha de Wiliam Howard, $1^{\circ}$. Barão Howard of Effingham. Robert foi criado na casa de seu pai e na de amigos de seu pai e tinha licença de visitar sua mãe sempre que quisesse (Adams 2008a, 2008b). Lady Sheffield acabou casando-se com Sir Edward Stafford em novembro de 1579, indo com ele para o continente europeu. Dudley teve uma excelente educação e foi matriculado no Christ Church, em Oxford, em 1587, com o estatuto de filius comitis, ou seja, filho de conde.

Em 1588, quando a Inglaterra era ameaçada pela Armada espanhola, Robert, então com 14 anos, juntou-se a seu pai, que comandava um exército em Camp Tilbury, preparando-se para resistir à invasão dos espanhóis.

O Conde de Leicester veio a falecer a 4 de setembro de 1588 (Warner 1899: viii), deixando para seu filho Robert uma grande herança, que incluía o castelo e as terras de Kenilworth. Com a morte de um tio, Ambrose Dudley, $3^{\circ}$. Conde de Warwick, Robert herdaria também os domínios (lordships) de Denbigh e Chirk (Wilson 1981: 336-337). 
Figura 1 - Robert Leiscester, $\mathbf{1}^{\circ}$. Conde de Leicester

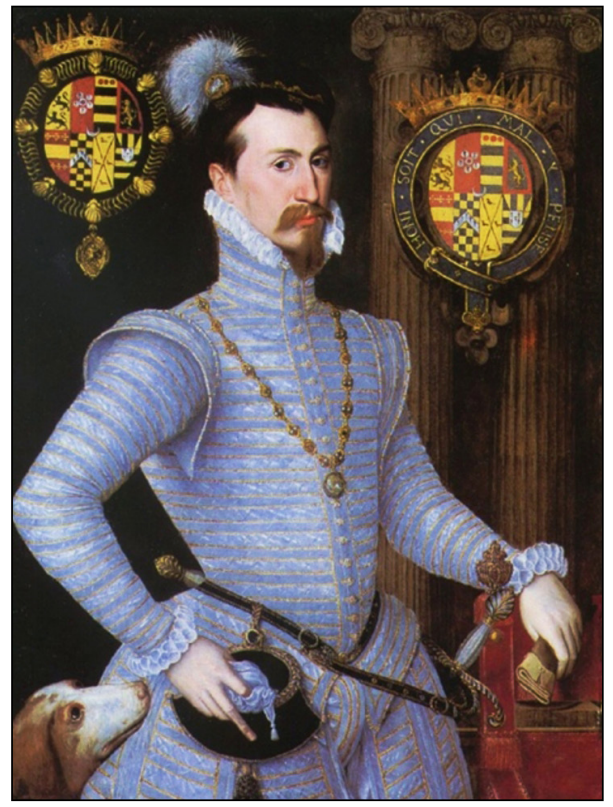

Figura 2 - Sir Robert Dudley, Duque da Nortúmbria e Conde de Warwick

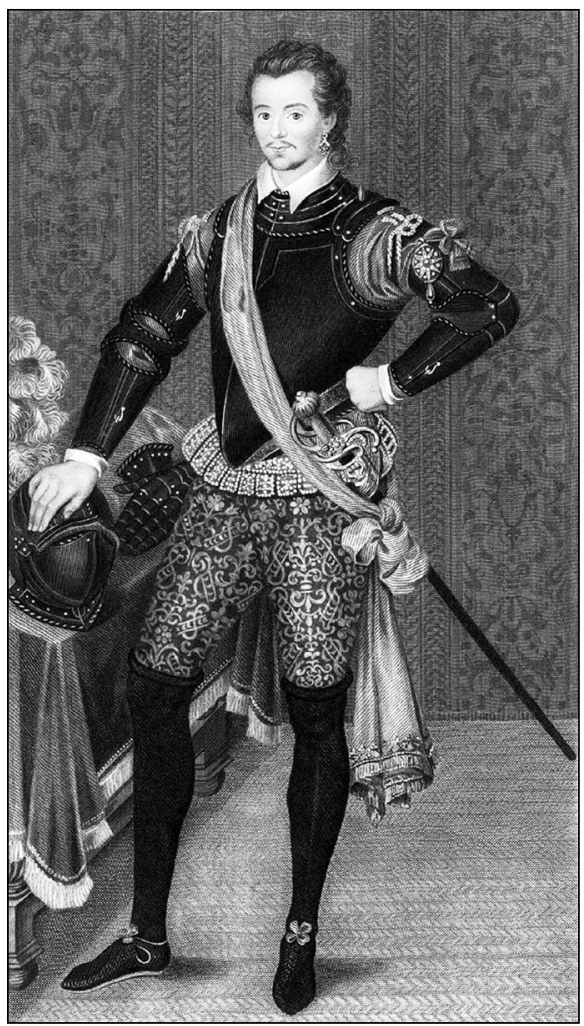


Em 1591 Dudley quis casar-se com Frances Vavasour, para isto contando com a autorização da rainha Elisabete I. Frances, entretanto, pediu a Dudley que esperasse até que ele fosse um pouco mais velho. Entrementes, ela casouse secretamente com Sir Thomas Shirley, no fim desse ano, sem a licença da soberana inglesa, sendo por essa razão banida da corte. Dudley, então com 17 anos, esposou, também secretamente, Margareth, filha de Sir Thomas Cavendish, sendo por sua vez também expulso da corte pela rainha, mas essa expulsão durou apenas poucos dias.

Em 1594 Dudley reuniu uma frota de navios, sendo a nau capitânia o galeão Beare, mais o navio Beare's Whelpe e as pinaças Earwig e Frisking. Pretendia com eles assaltar naves espanholas no Atlântico. A rainha não aprovou seu plano, devido a sua pouca idade e pelo custo dos navios. Ordenou-o então que se dirigisse para a Guiana. Dudley recrutou 275 marinheiros veteranos, incluindo o navegador Abraham Kendal e os capitães Thomas Jobson e Benjamin Wood. A frota de Dudley zarpou a 6 de novembro de 1594 para as Índias Ocidentais (cf. relatos da viagem em Dudley (1904) e Warner (1899)), mas uma súbita tempestade separou os navios e levou-os a diferentes portos. Dudley enviou mensagem ao capitão do Beare's Whelp para encontrá-lo nas Canárias. A má sorte continuou a persegui-los - o Earwig afundou. Em dezembro a expedição conseguiu capturar dois navios espanhóis em Tenerife. Dudley rebatizou-os como Intent e Regard, equipou-os com membros de sua própria tripulação e colocou o Capitão Woods em seu comando. Não tendo mais conseguido encontrar o Beare's Whelp, dirigiu-se a Trinidad (Figura 3), ancorando na Baía de Cedros em 31 de janeiro de 1595. Ali descobriu uma ilha, que tomou em nome da coroa inglesa, chamando-a Dudleiana. Zarpou depois para a baía de Paracoa para fazer reparos em suas naves e fez um reconhecimento de San José de Oruna ("S. Gioseppe" no mapa de Dudley (1661: 202), cf. Figura 3), mas decidiu não conduzir um ataque. Dividiu suas forças, enviando o Intent e o Regard para o norte. Em Trinidad recrutou um índio que falava espanhol e que prometeu acompanhá-lo em uma expedição a minas de ouro situadas no rio Orenoco. O guia desertou-o e Dudley regressou a Trinidad. Durante sua permanência nessa ilha, Dudley compilou uma lista de 69 palavras (com umas poucas frases curtas) em Arawak (tribo que ele designou pelo nome de Simerones) (cf. Dudley, 1661: 35-36 (em italiano, sob o subtítulo: Seguono alcune parole della lingua Indiana di Guiana,/ e dell'Isola della Trinidada, osseruate dall'Autore istesso, / quando fu quelle parti nel 1595) (Figuras 4-5); 1904: 211-212, em inglês (Figuras 6-7)). Essa lista foi reeditada por Penard (1928: 168-270), comparando os nomes nela constantes com o Arawak moderno do Suriname.

Em 12 de março de 1595 (poucos dias antes da chegada a Trinidad de Sir Walter Raleigh, à procura de Manoa ou Eldorado) a frota de Dudley dirigiu-se para o norte, onde capturou um navio mercante espanhol. Velejou depois até o 
Cabo Rojo, em Porto Rico, onde esperou certo tempo até obter presas, seguindo para a Bermuda. Uma tempestade forçou o Beare para o norte até a altura da Nova Inglaterra antes que a frota finalmente atingisse os Açores. Com poucas provisões e canhões em boas condições, Dudley velejou de volta à Inglaterra, mas encontrou-se com uma caravela espanhola no caminho. Conseguiu esquivar-se dela. O Beare chegou em St. Ives, na Cornualha, em maio de 1595, e Dudley ficou sabendo que o Capitão Woods havia apresado mais três navios.

Nesse mesmo ano de 1595, Dudley juntou-se a Robert Devereux, $2^{\circ}$. Conde de Essex, como comandante do Nonpareil, numa expedição contra Cádis, no sul da Espanha. Foi nomeado cavaleiro ( $\mathrm{Sir}$ ) por sua conduta nessa batalha.

Em 1597 enviou o Capitão Woods para a China, com os navios Beare e Beare's Whelp, viagem da qual nunca mais retornaram.

Figura 3 - Trinidad (Dudley, 1661: 202, detalhe)

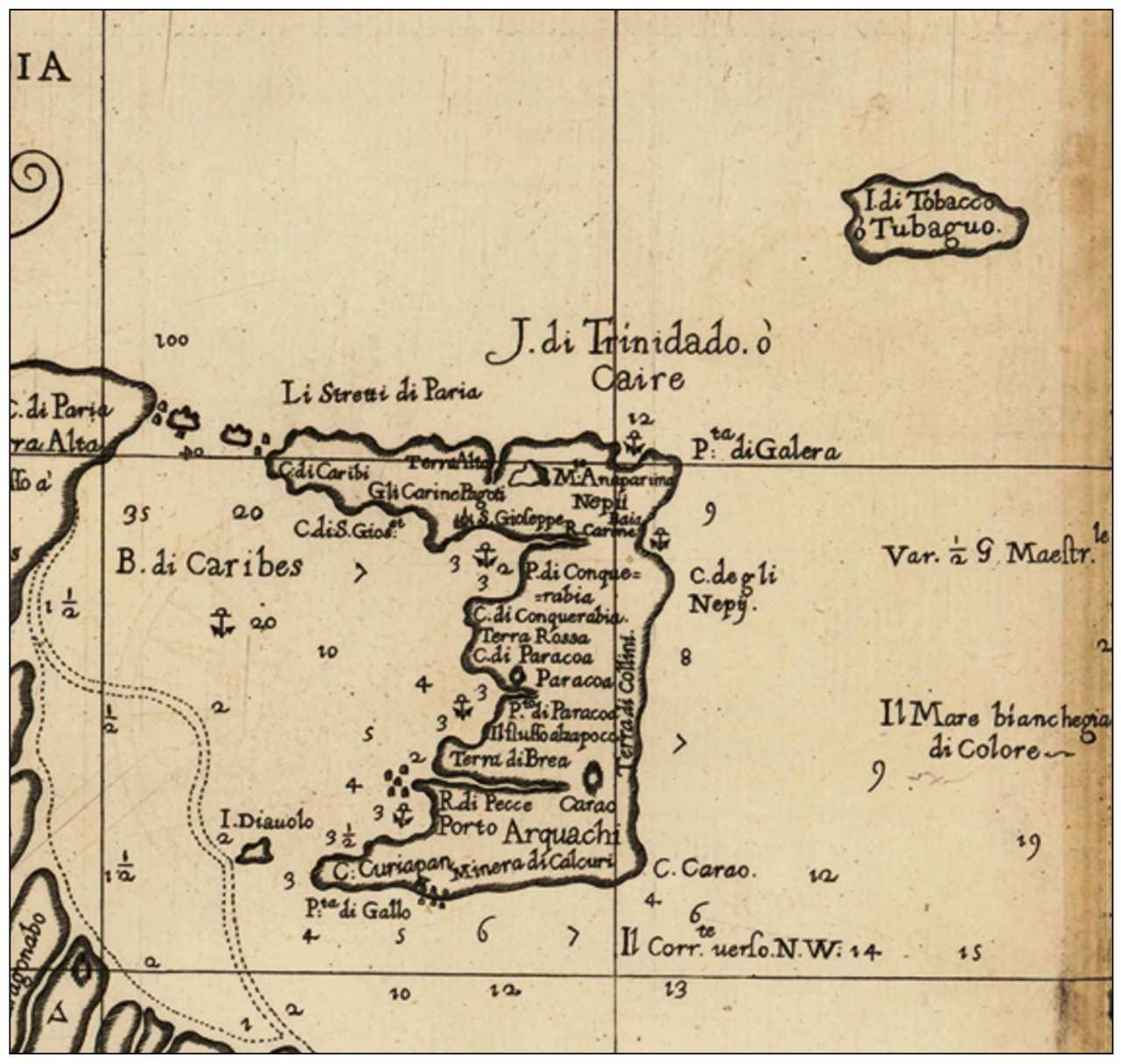


Figura 4 - Vocabulário Arawak (Dudley, 1661: 33)

\section{I B R O S E S T O.}

so pila ritornare per ildetto Capo, ma efcono francamen. te dal golfo di Caribes, per lo ftretto di Calcuri, vicino al capo di Paria, come principio della terra ferma dell'Indie; il che fi vede meglio per quefta Carta $1_{3}$. d'America; nella qual Carta, come di scala grande, fi vede minutamente tutti i pericoli degli fcogli, feccagne, edella corrente, con I'altre offeruazioni neceffarie de' venti, dell' aria, la qual'c faniflima per caufa de' venti fifli, eccettuatone i mefi di Giugno, Luglio, e Agotto, che quafi di continuo vi pioue, \& i venti fono variabili, e per caufa del caldo ercefliuo,e dell'humidità grande della Cofta, traria allora è mal fana,e produce delle febbri maligne, che ammanzaso gli ammalati in breue tempo; e perof fono noninate febbri cfimete, maligne, e peftilenti, delle quali porhi ne campano, non giouando ne meno il cabare fangue, anzi più toflto nuoce; \& in quefta ftagione i tempi fono cattivilfimi, per le trmpe. fte; e tuoni grandi, e fortune del mare orrendiffime, nominate dagl'Indiani Oracani, ò Vracani, che fono fericolofiffime in que' marid' affondare i vafcelli, benche fieno d'al. tobordo, e reggenti: La variaxione calamita dí quefta Carta c̀ gr. I. Maeftrale ; fe bene la Carta, per errore fatto nell intagliare, mette vn mezrogrado folamente: Le genti del paefe fono cattiuiffime, etraditore da non fidarfi punto del. le loro cortefie, maflime quelle nominate Caribes, che má. giano la carne humana, e combattono con gli altri Indiani per quefto fine, e fono comunemente più robufte di quelli.

DELLAMERICA, EDICHIARAZIONE della Carts decimaguets . S. I

Omincia quefta Carta con il rio Seavvano, di longitudine gr. 337 . e termina con il capo Palmas,di longitudine gr. 347. in circa, doue entra il gran fiume Maranghan : E la Colta fra quefto, \& il fiume Amazones è meglio modernata nella Carta is. feguente; però di quefta i 4 . c da fidarfene principalmente per la cofta di Guiana, che comincia con Seavvano, e finilfe con il capo del rio Amazones, nominato Arovvai , nel qual fume Amazones entrò il Capitano Roberto Thorntono Inglefe mandato in quelle partid'ordine, \& à fpefe del Serenillimo Gran Doca Ferdinando I. soo Signore.

Indetto Capitano ìdo, e ritornd feliceméte, e fe benenó ers mai ftato in quelle parti, nè anco nell'Indie Occiden. tali, in ogni modo, mediaste le Carte, \& inftruzioni fatte di propria mano dell' Autore, egli, per grazia di Dio, compliil viaggiofenza perdita di vn'huomo, che moriffe per malattié, efcoprì la cofta di Gaiana pid̀ efattamente, che fia mai ftato fatto per auanti ; $\mathrm{e}$ fcopridi più al beon porto di Chiana, che è porto Reale, e ficuro, il quale non fu mai benefcoperto da' Criftiani per itempi palfati; e di quiui coli meno feco cinque, ò fei Indiani per prefentare alle loro Alteze in Firenze, ficome fece ; iquali crano di quei $\mathrm{C}_{2}$. ribi, che mangiano la carne humana: Quefti morirno poi in Fireme, la maggior parte di vaioli, che à loro cे più infettofo della pefte iftefla, perche in detti paefi non hanno notizia di fimil male: Vno folo di quelli campò,il quale ferù poi in Corte per alcuni anni il Sereniffimo Principe Cardinale de' Medici, \& imparò à parlare comodamente bene la lingua Italiana.

Queft'Indiano di Chiana raccontaua fpeffe volte all'Autore, \& ad altri la fertilità, e ricchezza del regno di Guiana, e com'egli era ftato nella citta famofa di Monoa metro-

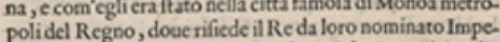
ratore, perche ha parecehi regni fotto il fuo Imperio; eche la Cirta cra ricca d'oro, efiruata vicino ad vn gran lago; c che effa Città era da otto giornate lunghe lontana dal porto di Chiana, effendo che gl'Indiani caminano velocemented piedi, efanno comunemente da so. miglia il giomo, e qualche volta piè. Diceua ancora il detrIndiano, che vicino à Chiana (qual'è paefe di colline) vi era vas miniera Parte Quarta , America.
A dargento affai ricca, che effi chiamano Perota, come anco dell'oro baffo, nominato da loro Calcuri, con il quale fan. no certe immagini, emezze lune per ornamento. Lifteffo diccua il fopranominato Capitano Thorntono ; e foggiungeua di più, che i ragnateli di quel paefé faceuano della fetas e che quiui fi trouaua del legno verzino in buona quantita, e delle canne faluatiche di zuechero,del pepe bianco, del legno pardo, della pitta, del ballamo, del cotone, e di molt'altre forte dimercanzic abbondanti per commerzios $e$ fe fuffe ben piantata da' Chriftiani, che l'aria era faniflima, el'entratura del Porto era comoda per fortificare, e per $\mathrm{co}^{\circ}$ mandare il Porto, con altre particolarità del paefe gia ftampate dall'Autore nel 1637 . come fopra fiè detto, alle quali per brevita fircferifce. Raccontauz ancora il detto Capi-

B tano, che quando bebbe fcoperto il rio Amazones, dO Oril. liano, nell' entrarui trouò vn Bornea, nominata cosi in lin. gua Inglefe, edx'Portughefi, Macarea; \& e fluffo fpauentofo, e pericolofo ne' eiorni della Luna nuous, e piena,notato quiainella detta Carta dall' Autore, in quelle parole. Gatadarevi de rme Bernos a hare 6 . e rn quarto; $\mathrm{e}$ con quefte poche parole d'aunertimento fi falnò il vifoello, per grazia di Dio, ela gente di S. A. fi come Fifteffo Capitano tettificò d S. A. S. e che fenza l'auuertimento in ifcritto della $\mathrm{Car}$ : ta, egli non haucrebbe faputo niente di tal pericolo, per effere poche di quefte Bornie al mondo ; e che fi farebbe perduto, le anticipatamente non fi fulfe audertito del pericolo, $\&$ addirizzato il vafcello conle gumine, \& in luogo più fie curo per riceucre la Bornia con la proda ; e cosìnon affon-

C dòil vafcello, ma ifcampò quel pericolo.

Da quef'éfempio fi poò vedere quanto importino gli auvertimenti in ifcritto delle Carte dell' Autore, per i pericoli manifetti, che in altre Carte comuni non fono notati, potendofic contre parole d'annotazioni faluare in diucife occafioni il vafcello, e la gente.

Dal detto rio Amazones il detto Capitano Thorntoro cofteggio la Guiana , con Fifola della Trinidada, o Trinita, \& hebbe grau fodisfazione nella verita, e perfezione della Carta deli' A utore, e dell'inftruzioni fue, principalmente, di principiare il viaggio nella ftagione migliore, che però ritornarono turti con buona falute, con buon tempo, e con ventifanorevoli. Cominciò il viaggio da Liuorno nel mefe di Settembrel'anno 1608 . in circa, e ritomd nell'iffeffo

D porto di Linorno alla fine di Giogno fegaente nel $1609 . \partial$ in circa.

\section{Sogueno alcune parole della lingua Inlieme di Griens,}

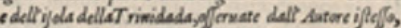
providefu in quelleparti nel 1595.

Dabarah, vewldire I capellidella tefta.

Guttemoc, Vn'huomo.

Deflie, Lafronte.

Tacofi, d Tafereth, Vn'occhio.

Archen, Identi.

E Daria, Legengine.

Defire, Lelabbra.

Dill, Aa :ate 3 Lalingua.

Dudica, $\quad$ L'orecehie.

Dacan, Lamano.

Dacabba, La palmadella mano.

Dadena, Il ipolifo.

Tacarle, 11 ginocchio.

Daddano, Li polpa della gamba.

Dabodda, Leditade' piedi.

Dacat, 1 piede,

Cattic. La Luna.

Tauratoth, Vnafune.

Archeano, d Arquiccona, Lecefoie.
Caervvoda, Vnaradicedolce.

Delacoac, Labocca. 
Figura 5 - Vocabulário Arawak (Dudley, 1661: 34)

12

Vreeuach, cions fonun in Cielo.

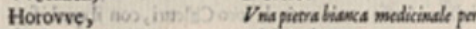

idderichloi.

Mointiman, $\quad$ Ferro, d̀ acciaio.

Hovva, Vngattomammone.

Caroto, $\quad$ Mineftra, ò pappa.

Sakel,

Techir,

Bodad,

Habdalle,

Mentinie,

Addehegacno,

Calcour,

Perota,

Aran,

Caulpire,

Taucorao,

Carparo,

Tibetebe,

Marahabo,

Semara,

Heculle,

Canaa,

Cacri,

Halete,

Caflique,

Caervioda,

Marifce, eMaix,

Yeddola,

Beyu,

Quecazuna,

Sumboler,

Callit, ১Hemaching,

Baru,

Oronuic,

Hilket,

Vvalhowa,

Vreit,

Barudda,

Bara,

Heldaro,

Addox,

Barennare,

Curaballa,

Sibath,

Tolleteillaro,

Vlaffo,

Boheri.

Non qquo,

Non quapo,

Babaghe conoafect,

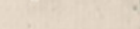

Ioftòbene.

Smaniglididonna.

Vna cafa, d̀ capannalero.

Insole.

Vn'allbero.

Voofpecchio.

Oro.

Argento.

Rame.

Pietra bianca.

Vma pietra Vedicris, dic chis.

mata dagh Spagnueli puetras

Hiadas.

Vna fpada.

Conchiglie, ò nicchi.

Vn'arco.

Vna freccia.

La corda dell arco.

Lelerbarchette.

Vniffola.

La radice Patata.

VnRe, ovn regolo.

$V$ na leno radice a bi dalct;

Grano Turchefco.

Va coltello.

Vaflauto, d̀ piffera.

Vna paniera.

Vn cappello alla Spagnuola

Pane, de efrifonwo, cume $b_{0}$

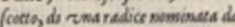

bro Indiani Caferea.

Acqua di fontana.

L'acqua del mare.

Fuoco.

Vn pappagallo.

Tabacco.

Vinpettine.

Acquas d'ogniforte.

Vn cucchiaio dilcgno.

Vna barchetta delic nofire, ò

vno fchifo.

Botroni di vetro.

Vus certa loropictra.

Ognipintra ingenarale.

Vn fonaglio.

Il pefce Toeno.

$V$ inpece, derowla.

Non lo so.

Non sò dire.

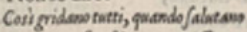

rons natue foreftiers por trafficere freo:

Dicono ancors babaghe por dire, come ftate: $E$ dicemo fec

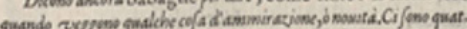

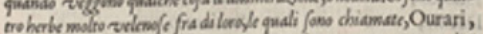
Caraffi, A parcepo, e Parapara: $V_{i}$ enow ascera quetro radici comera il vileow, cios, Tarars, Caturapama, Vappo, eMs. carto.

Addoch,

Queca,

Camano,

Vobaftone.

Calcuri,

Vna paniera Indiana.

Vn'ancora.

Oro, d la pietra marcafitaper.

che da qualla ne caseso anpoco

zomo.
A F

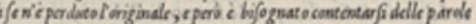
fopradctte, le quali ha rierowate in altre forthire.

\section{DELL'AMERICA, E DICHIARAZIONE \\ dollia Certs decumagwints. Cap. XXXVII.}

N quefta Carta fi mottra quello, che haneo ficoperto gli , piumodernamente della Carta precedente, w, ov. c pero circa il gran fiame d Amazoacs, o Orilliano; cominciando quefta Carta dal capo di North, o di Arovvai, perche quimi entra il golfo del detto fiume, di longitudine gr. 343. elatitudine gr. 1.e min. 40. Tramontana, e termina con il capo Palmas, doue conincia la bocca

B dal fume Maranghan ancor'cgli aflai grande, di longitudin:gr. 347. clatitudine del capo Palmas gr. 2. Auftrale : Il fo xdo della Cofta c̀ paffi due in circa, d'arena bianca, edi fango ancora: Il riparo migliore per naui, in quefta Cart3, è nel rio Flaman, \&anco nel golfo di Pafcoa, doue fi catra in tre paffi di fondo folamente, clic c̀ il fondo maggiore della Cotta ; ma petò non vi è Porto di confiderazione in tutta quefta Carta per afficurare naui grandi, come pacfe baflo,e di poco commerzio ; e perciò non occorre allungarfi nella dichiarazione, rimettendofiallifteffa Carta pervederela differenza di queita dalla precedente.

Il fumc Amazones fu anticamente nominato Tareta d Tapoi, e fu fcoperto da Orilliano Caualiere Spagnuolo; $\mathrm{c}$ coalieftefo fume finifconol Indic Orcidentali del Re Cat-

C. tolico, e comincia la Brafiglia de' Portughef fin'al rio dei. la Platta ; fe bene quefta non cे a bitata da loro fe non dal ca. ftel Delo fin'alla cittd, e porto di san Vincente nell s beiar di Santos; $e$ della cofta di Brafiglia, Fernamber he la catt), 8. il porto più ricco per zucchero, legno verzino, ed altre. nercanzic; febene la città di Todos Sanctos è metropoli doue rifiede il Goucrnatore del Re, \& il Configlio; ma gl'Indiani della Brafiglia fono nimici capitali de' Pontughefi, \& cffi Indiani vivono però più dentro la terra ferma ; c qualche volta hanno deli' oro, che lo trousno ne' fiumi più centro alla terra ferma, doue nos abitano i Chriftiani; s bene il fiume di Maranghan fu fcoperto da' Franzefi, i goali frequentauano gì affai quella Cofta in'al caftel Delo de' Portughefi: La corrente feguita La Cofta verfo Guiana:

D

\section{DELLAMERICA, E DICHIARAZION Ë} della Carta decimg fofa S. I.

Q Ata Carta comincia con il capo Palmas, douc en* c. x. delle, tra il fiume grande di Maranghan, di longitud. Bragliceset gr. 347. e latitudine gr. 2. Auftrale; \& il pro. Aorion montorio pü eminente della Colta verfo Leuante cil capo Bianco, o Blanco, di longitudine gr. 355 . c min. 9. e lati. tudine gr. 2. e min, 35. Auftrale, con alcune feccagne pericolofe intorno. La Cofta è affai ben pienal di fumi, (per effer terra baffa ) edi feccagee ancora; \& c̀ ftata frequentatagia da' Franzefi con naui piccole, per mancamento di

Portibeoni, \& haueuno commercio lolamentecon oll'to* diani del paefe, come inimicide' Portughefi, de'quali Indiani, guellidi Petaguer hanno dell'argento in buona quí. tita 3 fe bene oucti ono Caribi, emangiano la carne he mana: e paffito il cattel Delo de' Portughefi, la Cofta c̀ pericolofa affai per glifeogli, efecehe, fin'al fiume Paraiba, che è buon Porto in quattro paffi di fondo, \& anche per pi. gliare dell'acqua, ed altri rinfrefcamenti,e non eे loogo fortificato da' Portughefi, ancor che non fia molto lontano dal Porto, e dalla ricca citta di Fernambech, per commerzio di zuechero, everzino: La corrente feguita la Colta verfol'Tndie; ma però paflato Paraiba Grà difficile, per caufa de' venti contrarj, à trouare il capo sant' A goftino, fe non in certe ftagioni di venti Tramontani, come promon- 
Figura 6 - Vocabulário Arawak (Dudley, 1904: 211)

Here follow certaine wordes of the language of Trinidad which I observed at my being there.

Guttemock.

A man.

Tabairo, Dabarah,

Or Dabarra. $\}$ The heare of ones head.

Dessie

Dasereth, or Dacosi

Dalacoack

Archeh

Daria

Desire

Dill

Dudica

Dacan

Dacabbo

Dadena

Dacurle

Daddano

Dabodda

Dacutti

Cattie

Tauraroth

Arkeano

Weevah

Harowa
The forehead.

An eye.

The mouth. The teeth.

The gummes. The lips.

The tongue. The eares.

The palme of the hand.

The wrist.

A knee.

The calfe of the legge. The toes. The feete. The moone. A rope.

A paire of cizers. The heaven. A stone good for the head ache. 
Figura 7 - Vocabulário Arawak (Dudley, 1904: 212)

\begin{tabular}{|c|c|}
\hline $\begin{array}{l}\text { * The name } \\
\text { of the river } \\
\text { Orenoque may } \\
\text { seeme to be } \\
\text { derived from } \\
\text { this voord. }\end{array}$ & 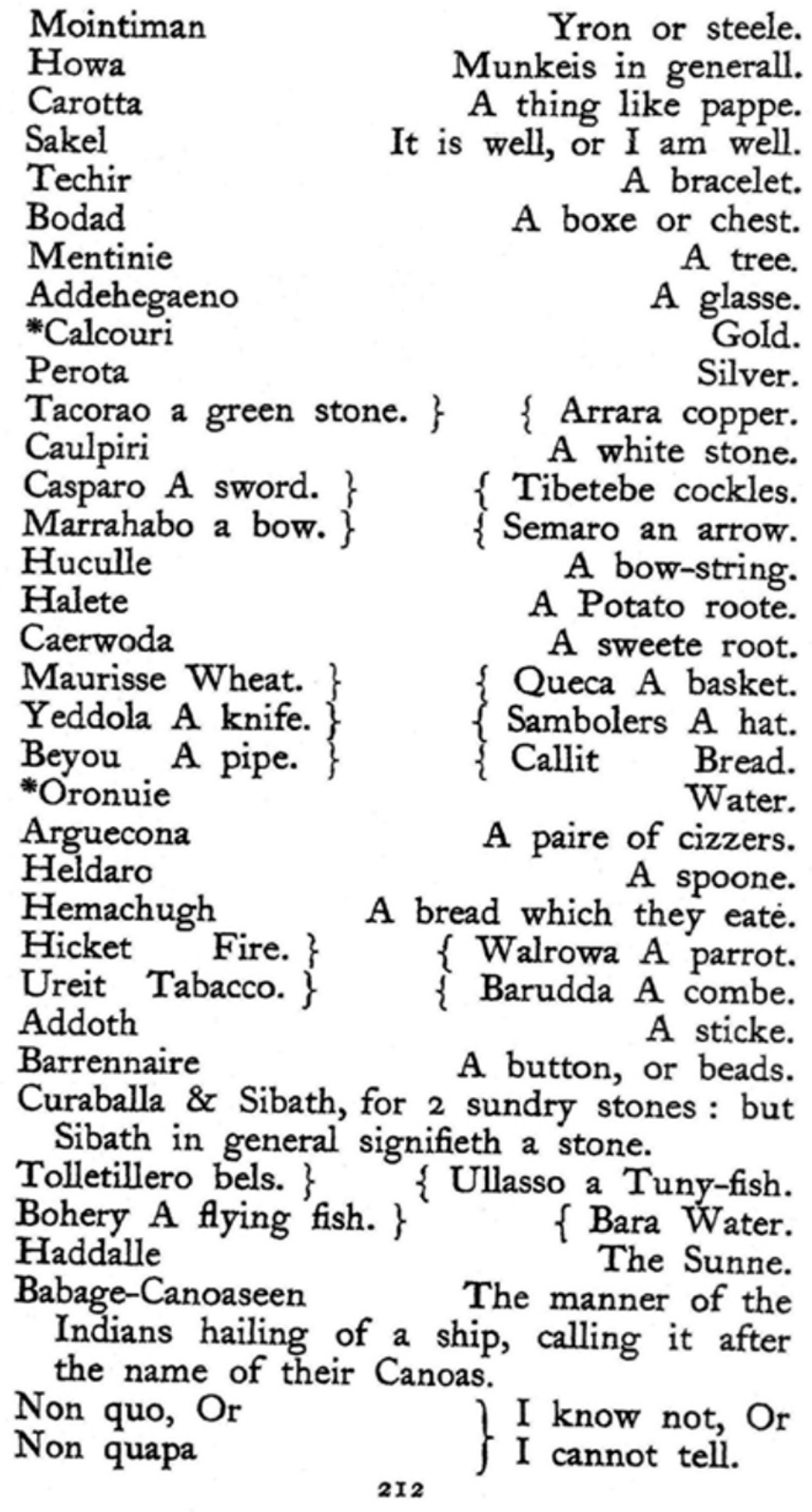 \\
\hline
\end{tabular}


Em 1605 Dudley abandonava definitivamente a Inglaterra, indo de início para Calais, acompanhado por sua prima e amante, Elizabeth Southwell, disfarçada como pajem. Elizabeth era filha de Sir Robert Southwell e Lady Elizabeth Howard, bisneta de Charles Howard, $1^{\circ}$. Conde de Nottingham e tio de Dudley. O casal declarou que havia se convertido ao catolicismo; casaram-se em Lyon, em 1606, após obter a dispensa papal, por serem primos. Foram em seguida instalar-se em Florença.

Dudley passou a usar o título de seu pai, de Duque de Leicester, e o título de seu tio, de Conde de Warwick.

Dudley começou a desenhar e construir navios de guerra para o arsenal da Toscana e tornou-se conselheiro naval de Fernando I, Grão-Duque da Toscana (30 de julho de 1549-22 de fevereiro de 1609), da família Medici; Fernando fora nomeado cardeal, mas com a morte de Francisco de Medici, a 19 de outubro de 1587 obteve do Papa Sisto V a dispensa do cardinalato para herdar o título de Grão-Duque (Figuras 8-9).

Figura 8 - Fernando de Medici como cardeal

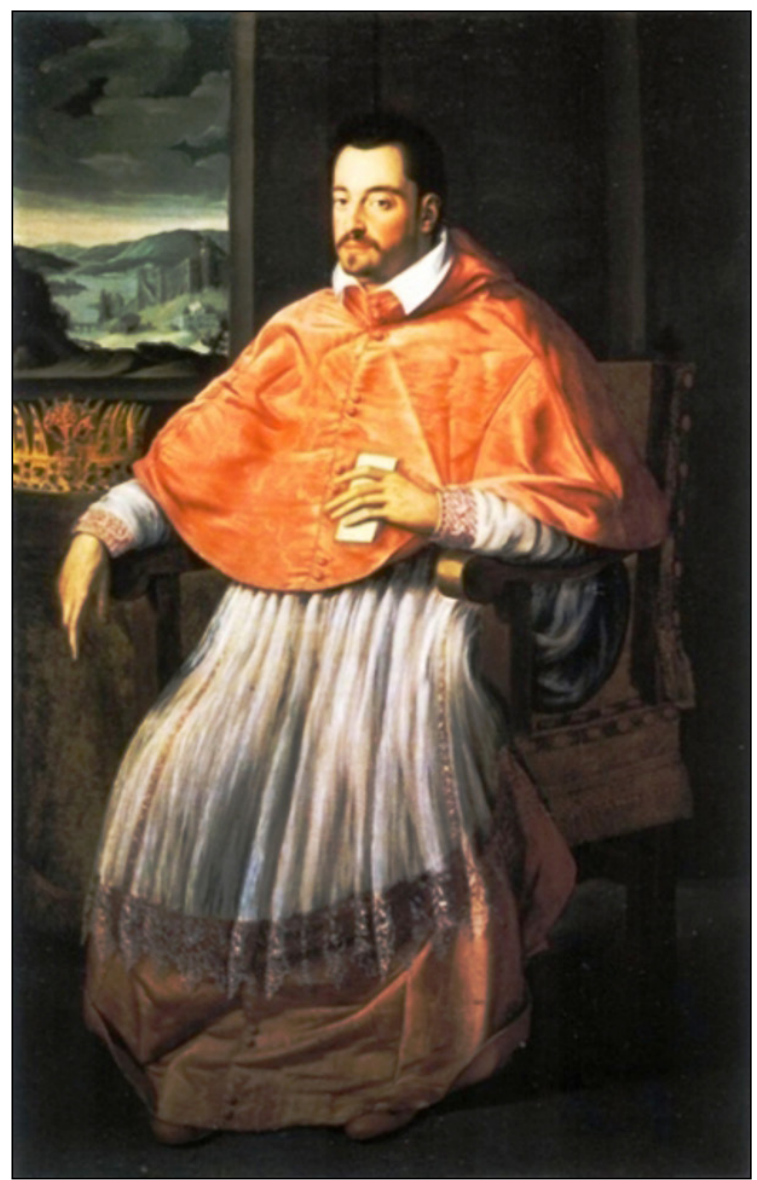


Figura 9 - Fernando de Medici como Grão-Duque da Toscana (Fernando I)

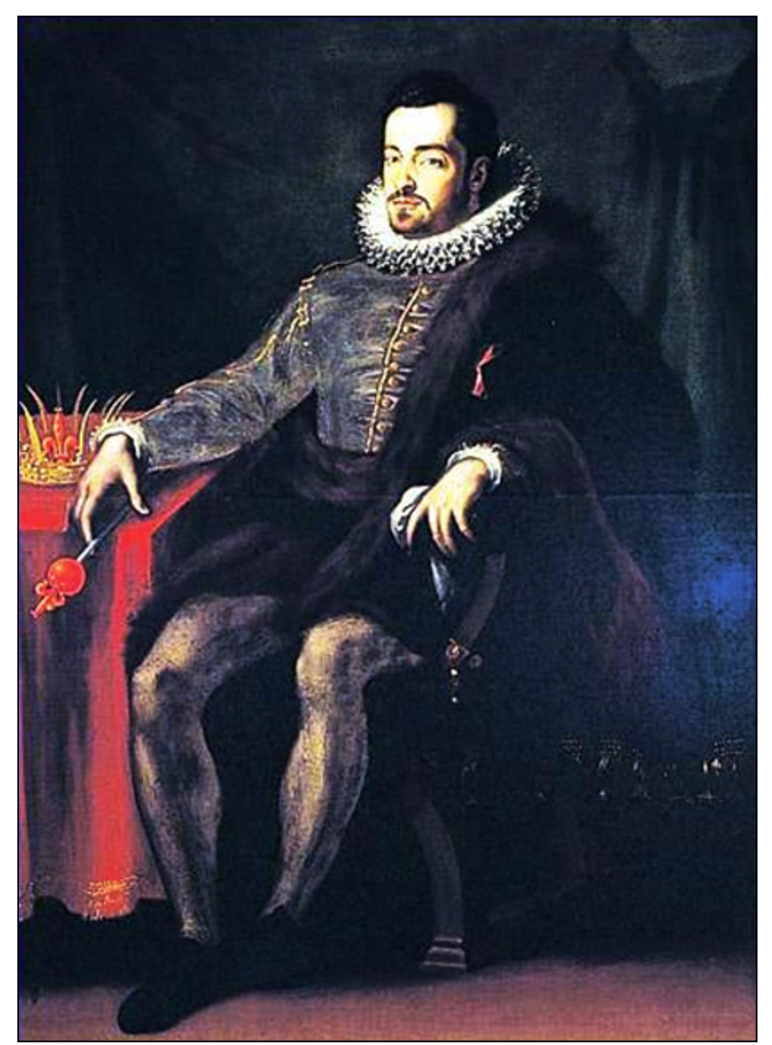

Dudley recebia do Grão-Duque uma anuidade de 2.000 ducados.

Em 1608, convenceu Fernando I a enviar o navio corsário Santa Lucia Buonaventura à Guiana e ao Norte do Brasil. Para fazer essa expedição, indicou William Davies, Cirurgião-Barbeiro de Londres (cf. Davies 1614, 1745; Wadsworth 1630; Ridolfi 1962; Holanda 1967, 2000; Zeron \& Camenietzki 1967, que apresentam vasta documentação sobre o tema; Neri 2000; Villani 2003; d'Angelo 2004; Sanfilipppo 2008; breves referências em Anônimo 1829a, 1829b; Smedley, Rose \& Rose 1845; Braudel 1966; Barão do Rio Branco 2012).

Segundo Lee (1888: 161):

"DAVIES, WILLIAM ( $f$. 1614), traveller, was a native of Hereford, and became a barber-surgeon in London. He states that he was a gentleman by birth, and served in many naval and military operations. On 28 Jan. 1597-8 he sailed in a trading-ship (the Francis) from Saltash, Cornwall, and reached Cività Vecchia, the port of Rome. He subsequently visited Algiers and Tunis. On leaving Tunis his ship was attacked by six galleys of the Duke of Florence. Davies was taken to Leghorn, where he worked as a slave for eight years and ten months. 
At the end of that period Robert Thornton, the English captain of a Florentine ship (the Santa Lucia), begged the duke's permission to take Davies with him as doctor on an expedition to the river Amazon. The duke demanded five hundred crowns as security for Davies' working under Thornton's orders, and the money was paid by Wiliam Mellyn of Bristol, who happened to be in Italy. Before leaving Leghorn the duke granted Davies an audience and received him with great kindness. Davies attributed the geniality of his reception to his perfect acquaintance with Italian. On returning to Italy Davies's ship was attacked by an English pirate, and an English sailor (Erasmus Lucas of Southwark) was fatally wounded. Davies landed with the body at Leghorn, and, declining to avail himself of the services of Roman catholic priests, proceeded to bury it by himself. While thus engaged he was arrested by the agents of the Inquisition; lived on bread and water in an underground unlighted dungeon for sixteen days, and after a first examination was removed to a large open prison. An English shipowner, Richard Row of Milbroke, helped him to escape, and after sailing about the Mediterranean he reached London in 1614 and wrote a full and interesting account of his travels (...)".

A $A$ true relation of the travailes and most miserable captiuitie of William Dauies, barber-surgion of London foi publicada por Davies em 1614 e teve outras edições (Davies 1625 [sem a narrativa sobre as Amazonas], 1745).

$\mathrm{Na}$ sequência, transcrevemos os trechos mais relevantes e acrescentamos sua tradução.

\section{A "DESCRIÇÃO E DESCOBERTA DO RIO DAS AMAZONAS” DE WILLIAM DAVIES, CIRURGIÃO-BARBEIRO DE LONDRES,}

FEITA EM 1608 (Davies 1625: 1287-1288)

"The Riuer of the Amazons lieth in the highest part of the West Indies, beyond the/ Equinoctial Line, to fall with this Riuer fortie leagues from Land you shal haue $8 . / 6, \& 7$ fathomes water, \& you shal see the Sea change to a ruddy colour, the wa-/ter shal grow fresh, by these signes you may run boldly in your course, and com-/ming neere the Riuers mouth, the depth of your water shal increase, then you shal/ make Discouerie of the Trees before the Land, by reason the Land is very low, and not higher in/ one place then another three foote, being at a Spring tide almost all ouer flowne, God knows/ how many hundred leagues. It stowes much water therewith with a verie forcible tide. In this Ri-/uer I continued tenne weekes, seeing the fashion of the people and Countrie there: This Coun-/trie is altogether full of Woods, with all sorts of wilde Beasts: as Lions Beares, Woolues,/ Leopards, Baboones, strange Boores, Apes, Monkeis, Martins, Sanguines, Marmosets, with/ diuers other strange beasts: also these Woods are full of Wild-fowle of all sorts, and Parrats/ more plentifull then Pidgeons in England, and as 
good meate, for I haue often eaten of them./ Also this Countrey is very full of Riuers, hauing a King ouer euerie Riuer. In this place is con-/ tinuall Tempests, as Lightning, Thunder, and Raine, and so extreame, that it continues/ most commonly sixteen or eighteen hours in four and twentie. There are many standing/ waters in this Countrie, which be full of Alligators, Guianes, with many other seuerall wa-/ter Serpents, and great store of fresh fish, of strange fashions. This Countrie is full of Muskitas,/ which is a small Flie, which much offends a Stranger coming newly into the Countrie. The/ manner, fashion, and nature of the people is this: They are altogether naked, both men and/ women, hauing not so much as one threed about them to couer any part of their nakednesse,/ the man taketh a round Cane as bigge as a pennie Candle, and two inches in length, through/ the which he puls the fore-skinne of his yard, tying the skinne with a piece of the rinde of/ a Tree about the bignesse of a small pack-threed, then making of it fast about his middle, hee/ continueth thus till hee haue occasion to vse him: In each Eare hee weareth a Reede or Cane,/ which hee bores through it, about the bignesse of a Swannes Quill, and in length halfe an inch,/ and the like through the midst of the lower lippe: also at the bridge of the Nose hee hangs/ in a Reede a small glasse Beade or Button, which hanging directly afore his Mouth, flies too/ and fro as hee speakes, wherein hee takes great pride and pleasure. Hee weares his Haire/ long, being rounded below to the neather part of his Eare, and cut short, or rather as I iudged/ pluckt bald on the crowne like a Frier. But their women vse no fashion atall to set forth them-/selues, but starke naked as they were borne, with haire long of their Heads, also theirs Breasts/ hang verie low, by reason they are neuer laced or braced vp: they doe vse to anoint their Bo-/dies, both Men and Women, with a kind of redde Earth, because the Muskitas, or Flies shall/ not offend them.

These people are verie ingenious, craftie, and treacherous, very light of foot, and good/ Bowsmen, whose like I haue neuer seene, for they doe ordinarily kill their owne food, as/ Beasts, Fowles, and Fish, the manner of their Bow and Arrowes is this. The Bow is is about/ two yards in length, the Arroe seuen foote. His Bow is made of Brasillwood verie curious, / his string of the rinde of a Tree, lying close to the Bow, without any bent, his Arrow made of/ Reede, and the head of it is a fish bone, hee kils a Beast in this manner: standing behinde a Tree,/ hee takes his marke at the Beast, and wounding him, he followes him like a Bloud-hound till he/ fall, oftentimes seconding his shoot: then for any Fowle be he neuer so little, he neuer misses him:/ as for the fish, hee walkes by the water side, and when hee hath spied a fish in the water, hee/ presently strikes him with his Arrow, and suddenly throwing downe his Bow, hee leapes into/ the water, swimming to his Arrow which hee drawes aland with the fish fastened to it, then/ 
hauing each kild his owne food, as well flesh, and fowle, as fish, they meete together, to the/ number of fiftie or sixtie in a company, then make a fire after this fashion: They take two stickes/ of Wood, rubbing one hard against another, till such time as they bee fired, then making of a/ great fire, euery man is his owne Cooke to broile that which he hath gotten, and thus they feed/ without Bread or Salt, or any kind of drinke but Water and Tobacco, neither doe they know/ what it means: In these Countries we could find neither Gold nor Siluer Oare, but great store/ of Hennes. For I haue bought a couple for a Iewes Harpe ${ }^{4}$, when they would refuse tenne shil-/lings in money. This Countrie is full of delicious fruite, as Pines, Plantines, Guaues, and Pota-/to Rootes, of which Fruits and Roots I would haue bought a mans burthen for a glasse Button/ or Bead. The manner of their Lodging is this: they haue a kinde of Net made of the rinde of a/ Tree which they call Hamas, being three fathoms in length, and two in breadth,/ and gathered//

at both ends at length, then fastning either end to a Tree, to the full length about a yard and/ halfe from the ground, when hee hath desire to sleepe, hee crepes vnto it. The King of euerie/ Riuer is knowne by this manner. He weares vpon his head a Crowne of Parrats feathers, of se-/uerall colours, hauing either about his middle, or about his Necke, a Chaine of Lions teeth or/ clawes, or of some other strange beast, hauing a woodden Sword in his hand, and hereby is he/ knowne to be the King: Oftentimes one King warres against another in their Canowes, which/ are Boats cut out of a whole Tree, sometimes taking one another, the Conquerours eates the/ Captiues. By this time ten weekes were spent, and being homewards bound, but not the/ same way that we came, for we sailed vnto the Riuer before thewinde, because/ it blowes there continually one way, which forces all shippes/ that come thither to returne by a con-/trarie way".

Davies (1745: 487) também tratou das Amazonas:

"The description of Morria, distant from England 1620 leagues.

"Morria is a small low island, lying in/ the River of Amazones, the highest part/ of the West-Indies. This island is alto-/gether inhabited by women, having no/ mankind among them; they go alto-/gether naked, using bows and arrows for/ the killing their food; the hair of their/

\footnotetext{
${ }^{4}$ Jew's harp. Berimbau de boca. A primeira citação do nome inglês é de Raleigh (1596: 109): "and had so many hens as was wonderfull, and if we would haue any we should send Jewes harpes, for they woulde giue for euery one two hens, we tooke an Indian and gaue him 500 harpes, the hens were so many that he brought vs, as were not to be numbred" (cf. também Schomburgk, 1848: 127). Teria Davies lido o relato de Raleigh?
} 
heads is long, and their breasts hang low;/ and whereas many here in England do/ imagine that they have their right breast/ seared or cut off, it is no such matter now, what hath been in times past $\mathrm{I} / \mathrm{know}$ not: for this of mine own know-/ledge, I have seen forty, fifty or three-/score of them together, each of them/ bearing bows and arrows in their hands, / going along by the sea-side; and when/ they spy a fish, they shoot at it, and strike/ it, and so throwing down their bows, they/leap into the water after their arrows, and/ bring the fish to land, fastened to the ar-/ row; and so in all other things, as well/ the dressing of their meat, as their lodg-/ings and customs, they resemble and imi-/tate the Indians of the river of Amazons,/ as you heard before in that discouse. But/ some of these women do use to bear their/ children upon their backs, in this man-/ner: They take a piece of the rind of a/ tree, and with one end thereof they fasten/ the child's hams, and about the arm-pits/ and shoulders with the other, and so hang/ him on their backs like a tinker's budget ${ }^{5}, /$ and cast up the breast to him over the shoulder. The reason wherefore this/ island is inhabited by women only, is this:/ One month in the year, the Men from/ each side of the main land come in their/ canoes over to the island, every man/ matching himself with a woman, living/ there a month; and what men children/ they find there, they carry away with/ them, and the women children they leave/ behind with the mothers: and this is/ their use once a year, whereby this island/ is altogether inhabited by women. There/ is one thing more to be wonder'd at, that/ I have also seen, that is to say, very good/ oysters ands muscles growing upon trees,/ for I have eaten my part of many an/ hundred of them: and for your better/ understanding how they grow, you shall/ know that the Trees stand near the sea-/side, and at every full tide the boughs/ hang into the sea a fathom, or a fathom/ and an half, so that when the tide goes/ out, they are found hanging in great/ cluster upon the branches, like barnacles/ o the side of a ship, and at the coming/ in of the tide, their receive their moisture".

\section{Tradução}

"O rio Amazonas fica na parte mais superior das Índias Ocidentais além da linha equinocial; para encontrar esse rio, a 40 léguas da terra, terás

\footnotetext{
${ }^{5}$ Palavra registrada no inglês desde 1432 como bogett, bouget, bowgette ("bolsa de couro"), do francês arcaico bougette, diminutivo de bouge, que por sua vez provém do latim bulga ("bolsa de couro, fole").

${ }^{6}$ Uma tradução foi publicada por Zeron \& Camenietski (1967: 181-184). Outra, bastante livre, foi feita pelo Prof. Dr. Jean Marcel Carvalho França, professor de história da Universidade Estadual Paulista (Unesp/Franca), e publicada na Folha de São Paulo de 13 de abril de 2003 [cf. www1.folha.uol.com.br/fsp/mais/fs1304200308.htm].
} 
8.7 e 7 braças de água, e verás o mar mudar para uma cor avermelhada, e a água tornar-se-á doce; com estes sinais podes seguir firme em teu curso e chegando perto da boca do rio, a profundidade da água aumentará - então, farás a descoberta de árvores antes que de terra, porque a terra é muito baixa, nunca mais alta num lugar que noutro senão por três pés, sendo na maré viva quase toda inundada, Deus sabe por quantas centenas de léguas. Com isto, muita água ali se acumula, com uma correnteza muito forte. Neste rio permaneci dez semanas, vendo a feição da gente e da região. Esta região é completamente cheia de florestas, com todos os tipos de animais selvagens, como leões, ursos, lobos, leopardos, babuínos, estranhos porcos-do-mato, monos, macacos, martas [Mustelidae], saguis [Davies usa tanto sanguines como marmosets; ambos têm o mesmo sentido], com diversas outras e estranhas bestas; essas florestas estão também cheias de aves silvestres de todos os tipos, e os papagaios são mais abundantes do que pombos na Inglaterra, e de boa carne, pois comi-os frequentemente. Esta região também está muito cheia de rios, tendo um rei em cada rio. Neste lugar há contínuas tempestades, raios, trovões e chuva, e tão extremos que continuam comumente por 16 ou 18 horas, das vinte e quatro. Há muitas lagoas nesta região, que estão cheias de jacarés, iguanas, e muitas outras e variadas serpentes aquáticas, e grande abundância de peixes de estranhas feições. A região está cheia de mosquitos, que são uma pequena mosca que muito ataca o forasteiro recém-chegado à região. O modo, feição e natureza deste povo são os seguintes: andam totalmente nus, tanto homens e mulheres, não tendo nem um fiapo sobre si para cobrir qualquer parte de sua nudez; o homem toma um canudo redondo do tamanho de uma vela de um vintém, com duas polegadas de comprimento, através do qual puxa o prepúcio de sua verga, amarrando a pele com um pedaço da casca de uma árvore da grossura de um fino barbante, então amarrando-a no meio; ele assim continua até ter necessidade de usá-la. Em cada orelha traz um caniço ou cana, que atravessa nela, quase do tamanho de uma pena de ganso e do comprimento de meia polegada, e outro semelhante através do meio do lábio inferior; também pendura no septo nasal um fio com uma pequena conta de vidro, ou botão, que, ficando pendurado em frente à boca, voa para frente e para trás quando ele fala, do que ele tem um grande orgulho e prazer. Usa seu cabelo longo, cortado arredondado abaixo da parte inferior de sua orelha, ou então, como vi, raspado e careca no topo da cabeça, como a coroa de um frade. Suas mulheres nada costumam colocar sobre si, e andam tão nuas como nasceram; suas cabeças têm longos cabelos; seus seios ficam muito pendentes, pela razão de nunca serem enlaçados ou suspendidos. Costumam untar seus corpos, ambos mulher e homem, com uma espécie de terra vermelha [sic; urucum], para que os mosquitos não os molestem. 
São gente muito engenhosa, finória e traiçoeira, muito rápida no caminhar e bons arqueiros, como nunca vi semelhantes, pois comumente matam sua própria comida, tal como bestas, aves e peixes; a maneira como usam seu arco e flechas é a seguinte. $\mathrm{O}$ arco tem cerca de duas jardas de comprimento e a flecha sete pés. O arco é feito de pau-brasil e muito curioso - sua corda é feita de casca de árvore e fica junto ao arco, sem nenhuma envergadura; suas flechas são feitas de caniço e a ponta é um osso de peixe; matam um animal desta maneira: postando-se atrás de uma árvore, miram o animal e, ferindo-o, seguem-no como cães de caça até que caia, frequentemente flechando-o uma segunda vez; quanto às aves, por menores que sejam, eles nunca erram; quanto aos peixes, eles caminham à beira d'água e quando veem um peixe n'água imediatamente atingem-no com uma flecha e, rapidamente lançando ao solo seu arco, pulam n'água, nadando até a flecha, que trazem para terra com o peixe cravado nela; então, tendo cada qual matado sua própria comida, como carne, e peixes, e aves, reúnem-se, 50 ou 60 num grupo, e fazem fogo desta maneira: tomam dois gravetos de pau, esfregando firmemente um no outro, até quando se inflamam, e então, fazendo uma grande fogueira, cada homem é seu próprio cozinheiro, assando o que obteve e assim se alimentam, sem pão nem sal, ou qualquer outra espécie de bebida, senão água e tabaco; nem mesmo sabem o que [pão e sal] significam. Nessas regiões não achamos nem jazidas de ouro nem de prata, mas grande quantidade de galinhas. Comprei duas por um berimbau de boca, após haverem eles recusado dez xelins em moeda. Esta região está cheia de frutas deliciosas, como abacaxi, goiabas e mandioca, de cujas frutas e raízes poder-se-ia comprar a carga de um homem por um botão ou uma conta de vidro. Seu tipo de acomodação é este: têm uma espécie de rede feita de casca de árvore, a que chamam Hamas, tendo três braças de comprimento e duas de largura, e arrepanhada nas duas extremidades, que são então amarradas numa árvore, à altura de cerca de uma jarda e meia do chão; quando têm vontade de dormir, metemse dentro dela. $\mathrm{O}$ rei de cada um dos rios é conhecido pela seguinte maneira: usa sobre a cabeça uma coroa de penas de papagaio de várias cores, ou as de algum outro animal estranho, pendura uma espada de madeira na mão e dá é reconhecido como rei. Frequentemente o rei guerreia contra outro em suas canoas, que são botes feitos a partir de uma árvore inteira; às vezes tomando um ao outro, os conquistadores devoram os cativos. A esta altura dez semanas se passaram e dirigimonos para casa, mas não da maneira como viemos, pois velejamos pelo rio à frente do vento que sopra ali continuamente nessa direção, o que força todos os navios que ali chegam a voltar de maneira diferente".

"Morria é uma ilha pequena e baixa, localizada no rio das Amazonas, a parte mais superior das Índias Ocidentais. Esta ilha é totalmente 
habitada por mulheres, não havendo homens entre elas; todas andam completamente nuas, usando arcos e flechas para matar seu alimento; o cabelo de suas cabeças é longo e seus seios caídos; apesar de haver muitos na Inglaterra que imaginam terem elas o seio direito queimado ou cortado, hoje não é verdade; como foi no passado não sei; pois delas conheci 40, 50 ou 60 juntas, trazendo arcos e flechas em suas mãos, caminhando ao longo da praia. Quando veem um peixe, atiram nele e, deixando seus arcos, saltam n'água em busca de suas flechas e trazem o peixe para terra, preso à flecha. Em todas as outras coisas, tanto na preparação da carne, quanto em sua acomodação e costumes, elas se assemelham e imitam os índios do rio das Amazonas, como já haveis ouvido neste discurso. Algumas dessas mulheres costumam levar as crianças em suas costas, desta maneira: tomam um pedaço de casca de árvore e enrolam a nádega da criança com uma extremidade e com a outra seus cotovelos e ombros, e lançado acima do seio sobre os ombros, como a bolsa de couro de um funileiro ambulante. A razão pela qual esta ilha só é habitada por mulheres é esta: durante um mês por ano, os homens de cada lado da terra firme chega em suas canoas até essa ilha, cada homem unindo-se com uma mulher e ali vivendo por um mês; toda criança masculina que ali encontram, levam com eles; as crianças femininas deixam para trás com suas mães; e é seu costume uma vez ao ano, donde esta ilha ser completamente habitada por mulheres. Há mais uma coisa a ser admirada, que eu também vi, ou seja, ostras e berbigões muito bons que crescem sobre árvores ${ }^{7}$, pois de minha parte comi centenas deles; e para que melhor entendais como crescem, deveis saber que essas árvores ficam à beira-mar e que a cada maré cheia os ramos mergulham por uma braça no mar, ou braça e meia, de modo que quando a maré se retira, eles são achados em grandes pencas nos ramos, como as cracas no lado de um navio que, com a chegada da maré, dela retiram sua umidade".

Enquanto no século XVI as poucas viagens pelo Amazonas (Diogo Nunes (1538), Orellana (1541-1542), Pedro de Ursua e Lope de Aguirre (1559-1561)) eram feitas rio abaixo (cf. Porro 1993; Papavero, Teixeira, Overal \& Pujol-Luz 2002), na virada do século XV e no início do XVII os holandeses já subiam o rio, estabelecendo comércio com as tribos ribeirinhas. Assim, Laet (1633: 634; Lib. XVII, cap. V: Brevis narratio eorum qua à Belgis in his partibus fuerunt gesta) narrava que:

"Alii deinceps succedentibus annis etiam magum Amazonum flúmen adire \&/ lustrare sunt aggressi; in quo potissimum Zelandorum opera atque industria eni-/tuit, adeo ut etiam colonias ad fluminis hujus ripas deducere \& duas arces hic mo-/liri non dubitaverint; unam quidem,

\footnotetext{
${ }^{7}$ Sobre os mangues.
} 
quam Nassavicam dixerunt in Coyminne. Quae/ instar insulae angusto fluminis ramo à reliqua Continente disjungitur ad milliaria/ pene viginti; distabat autem haex arx circiter octuaginta milliaribus ab ostio flumi/ nis Amazonum. Anteram, quam Auraicam nominarunt circiter septem milliaribus infra priorem. Juxta utramque denique \& agris colendis \& commerciis com barbaris exerceridis gnaviter incubuerunt".

Ou seja, que os holandeses da Zelândia haviam construído no Amazonas dois pequenos fortes e moradias, um deles chamado Nassau, construído em Coyminne, um tipo de ilha com 18 a 20 milhas de comprimento, mas estreita e separada do continente por um paraná e distante cerca de 80 léguas da boca do rio. O outro, chamado Orange, ficava a 7 léguas abaixo do primeiro. Esses dois fortes são situados num mapa de Robert Dudley (1661) no rio Parnayba ou Xingu (Edmundson 1903: 1-2).

Poucos anos depois, na narrativa de Master John Wilson de Wansted (Puchas 1906b: 345), consta que:

"After a few daies rest at Wiapoco, the Indians/ advertised us of three Ships which were in the River/ of Amasons, and that one of them would come unto/ us to the River of Wiapoco some two moneths after,/ which proved to be true, but by what meanes they knew it I could not imagine...".

Edmundson (1903: 2) ensina-nos que esse navio era o Hope, de Amsterdam, capitaneado pelo inglês John Sims, que fazia comércio com os indígenas a favor dos comerciantes daquela cidade.

A viagem de Davies, também rio acima (mas não sabemos o quanto penetrou rio acima), representou a única tentativa de estabelecer uma colônia italiana na boca do Amazonas.

Voltando agora a falar de Dudley: além da construção de navios, ocupou-se na Toscana de muitos outros projetos, incluindo o quebra-mar de Livorno e as fortificações do porto, a drenagem de pântanos e a construção de seu próprio palácio, feito em 1613 (Figura 10).

Sua obra mais importante, entretanto, foi o Dell'Arcano del Mare (Sobre o segredo do mar) (Dudley 1646-1648, em quatro volumes). Esse impressionante e minucioso tratado de astronomia, navegação, construção naval e cartografia inclui 130 mapas, todos de sua própria criação e não copiados de outras fontes, como era costumeiro na época; reúne todos os conhecimentos náuticos desse tempo. Os mapas das costas do nordeste da América do Sul, do Brasil e do rio La Plata constantes dessa edição foram reproduzidos na segunda edição (Dudley 1661) (Figuras 11-17); são notavelmente detalhados e mostram os nomes das tribos indígenas. 
Figura 10 - Vista atual do palácio de Dudley, na Via de’ Tornabuoni, em Florença

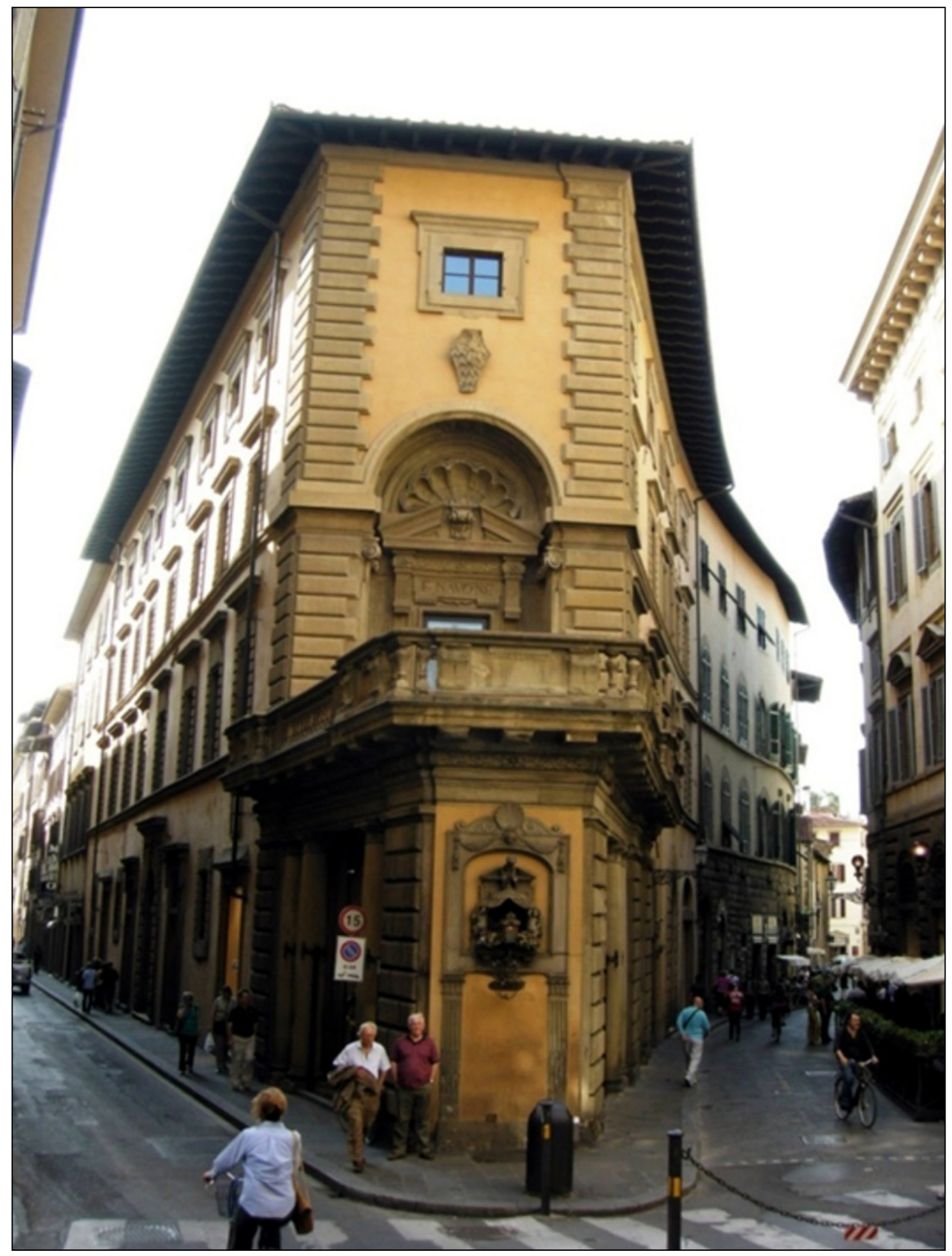


Figura 11 - Costa nordeste da América do Sul (Dudley, 1661: 202)

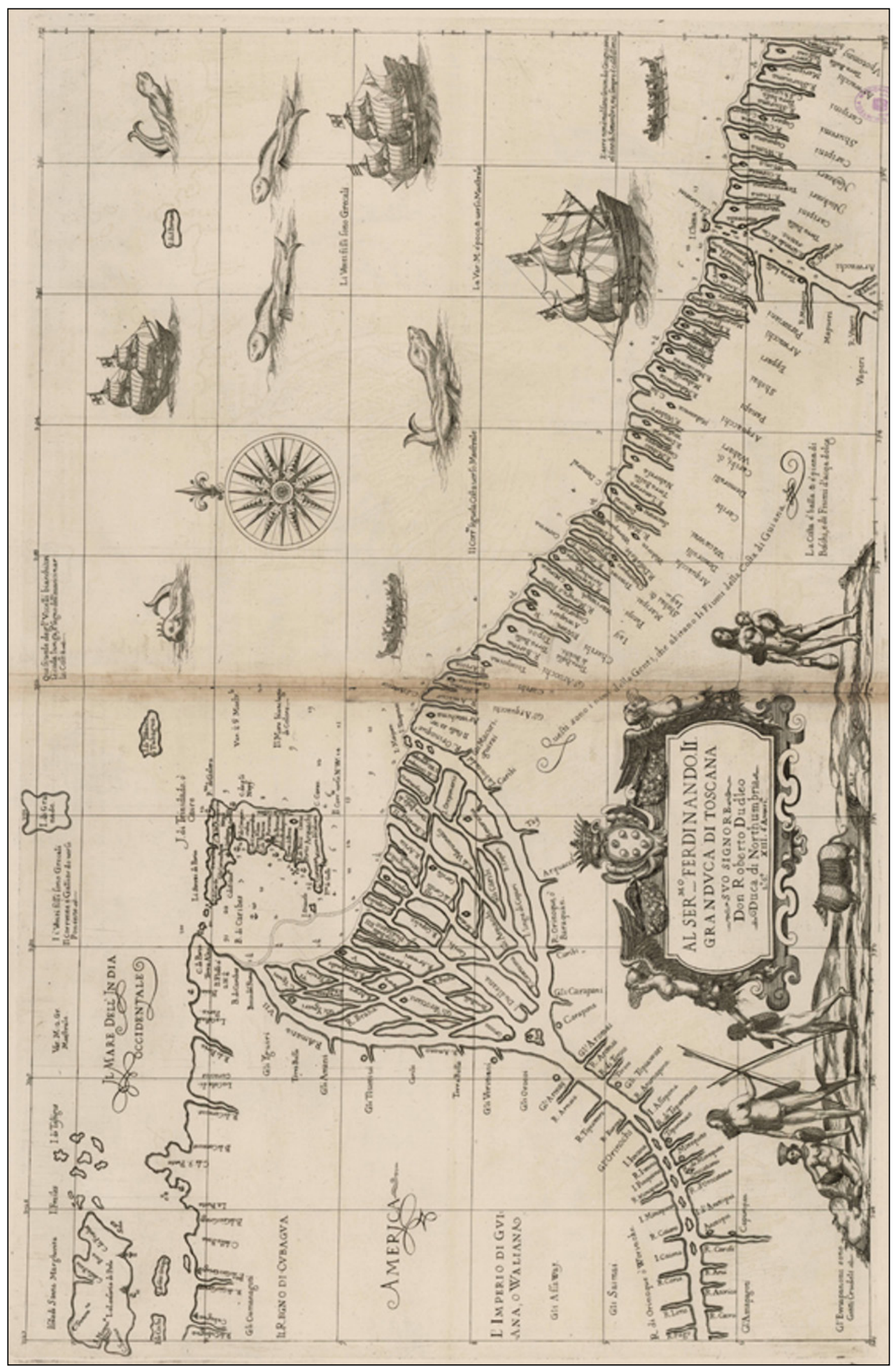


Figura 12 - Mapa da costa do Brasil (1) (Dudley, 1661: 204)

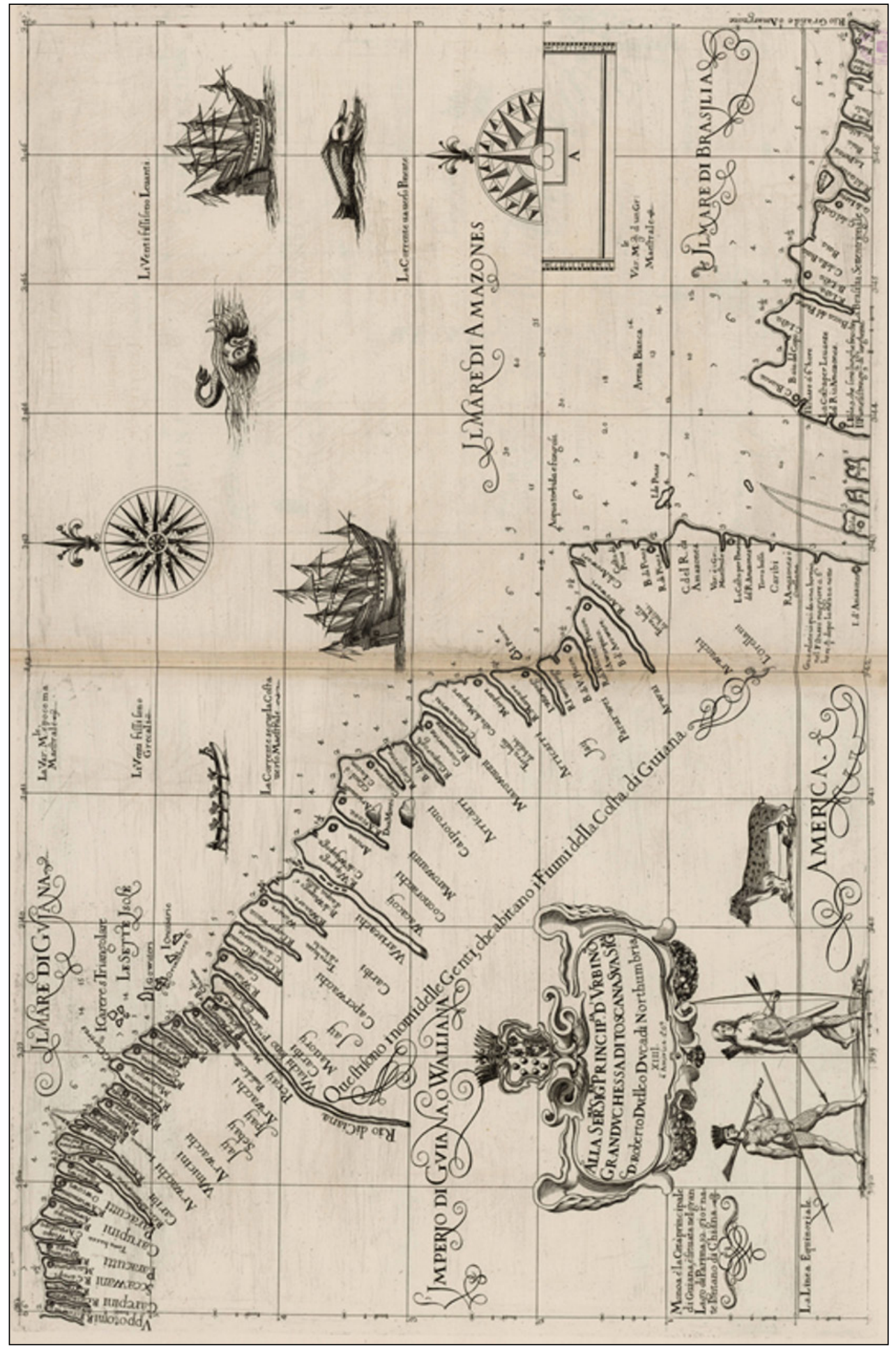


Figura 13 - Mapa da costa do Brasil (2) (Dudley, 1661: 205)

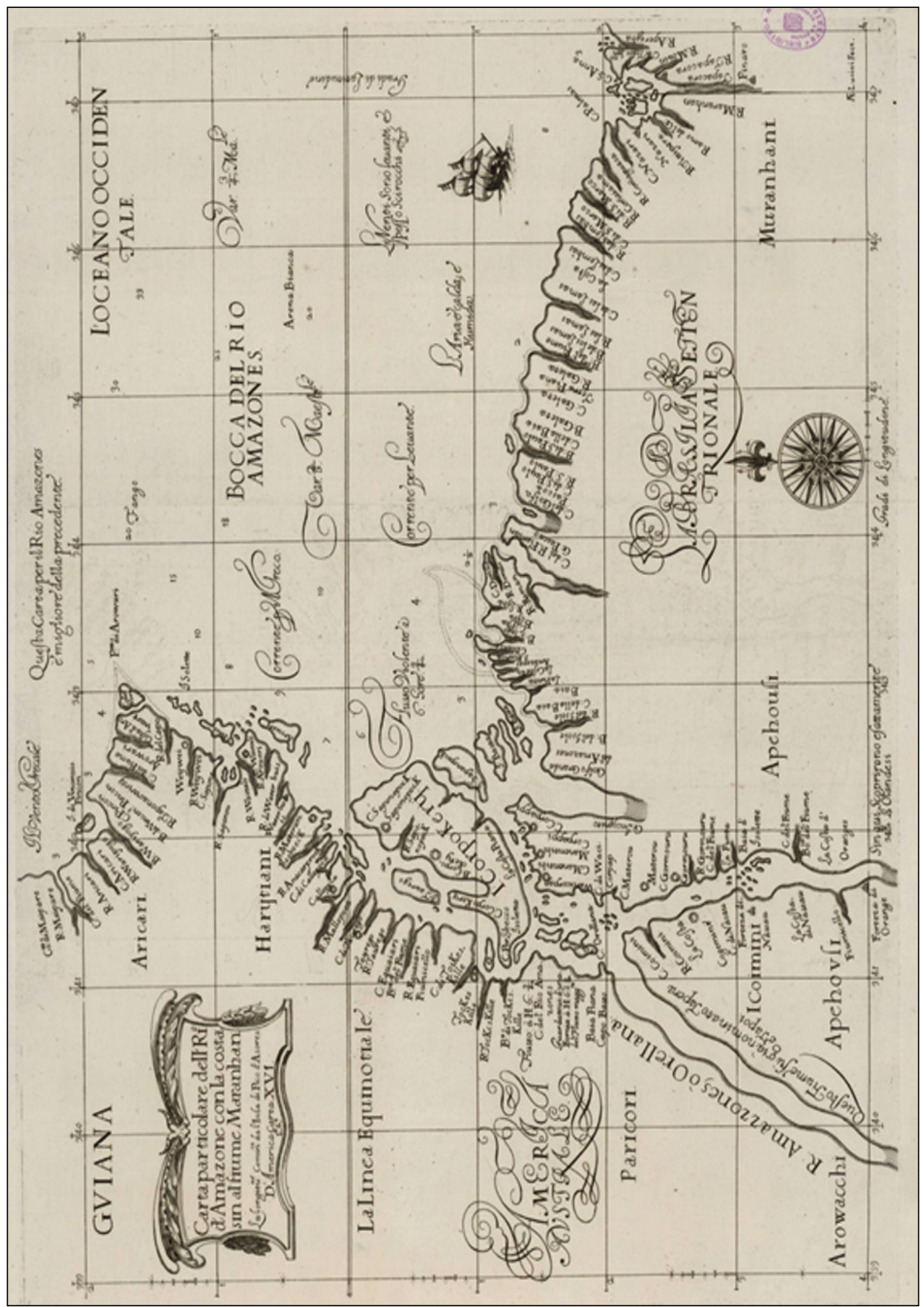


Figura 14 - Mapa da costa do Brasil (3) (Dudley, 1661: 207)

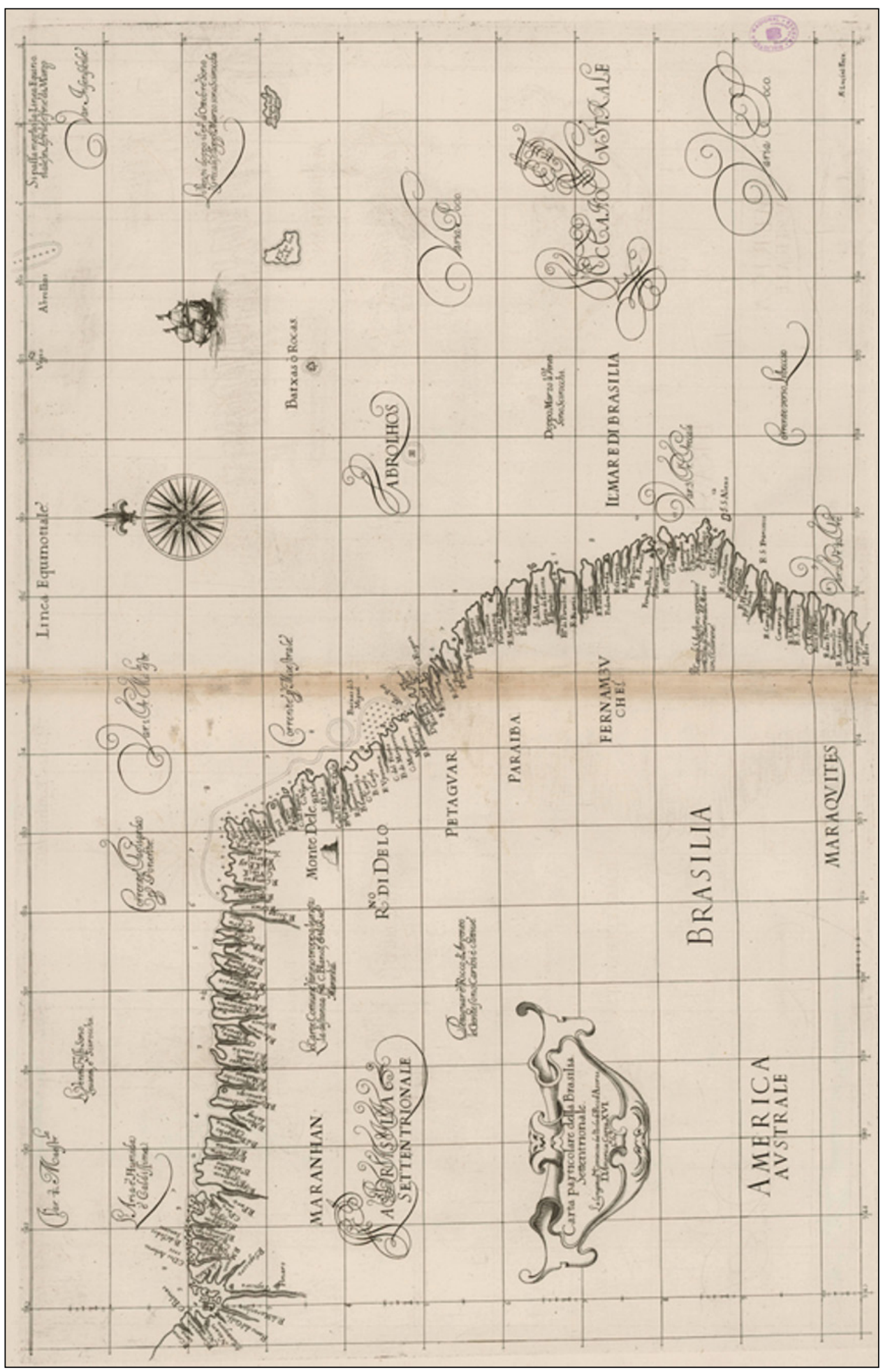

194 Revista Brasileira de Linguística Antropológica 
Figura 15 - Mapa da costa do Brasil (4) (Dudley, 1661: 209)

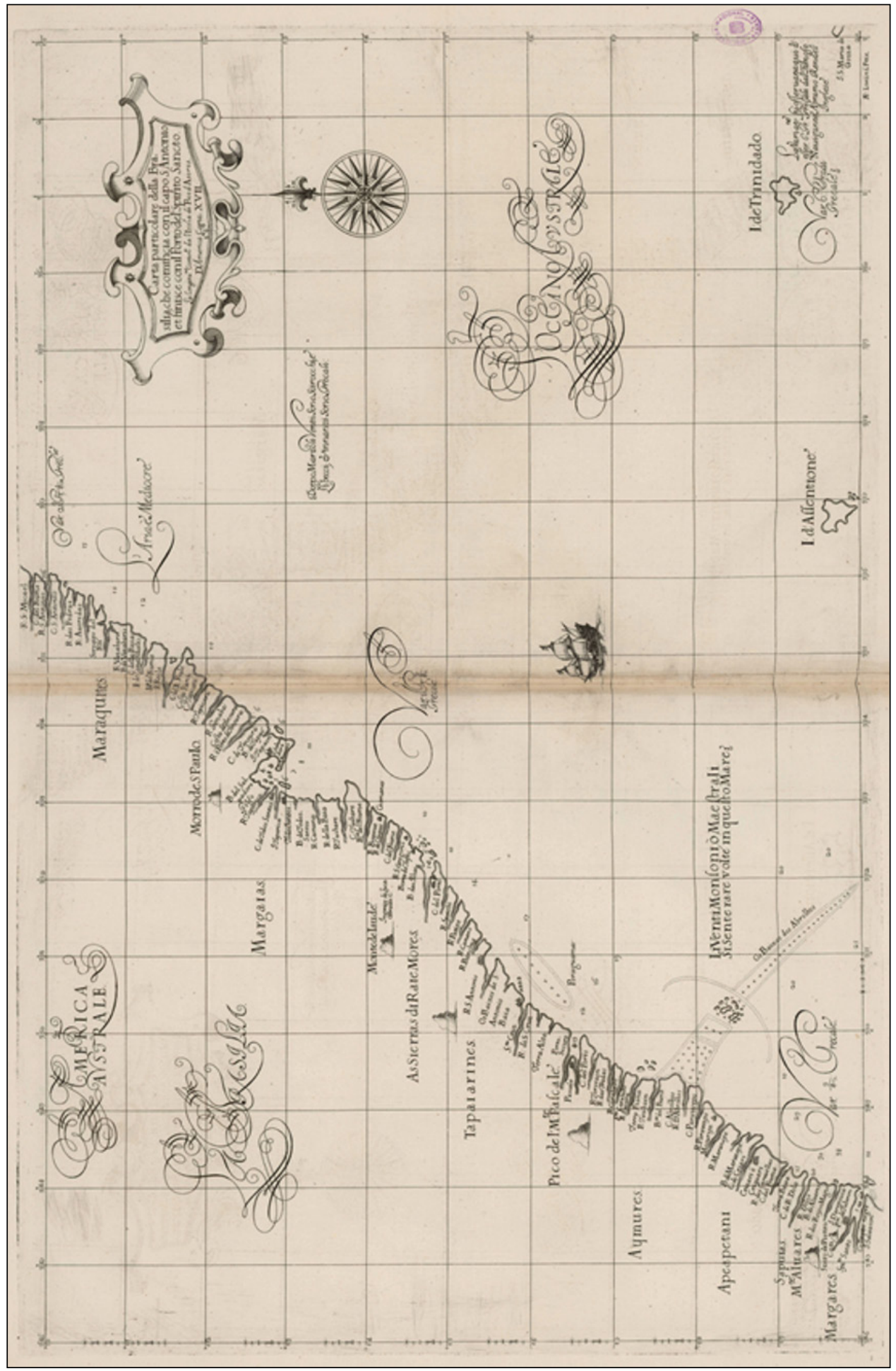


Figura 16 - Mapa da costa do Brasil (5) (Dudley, 1661: 212)

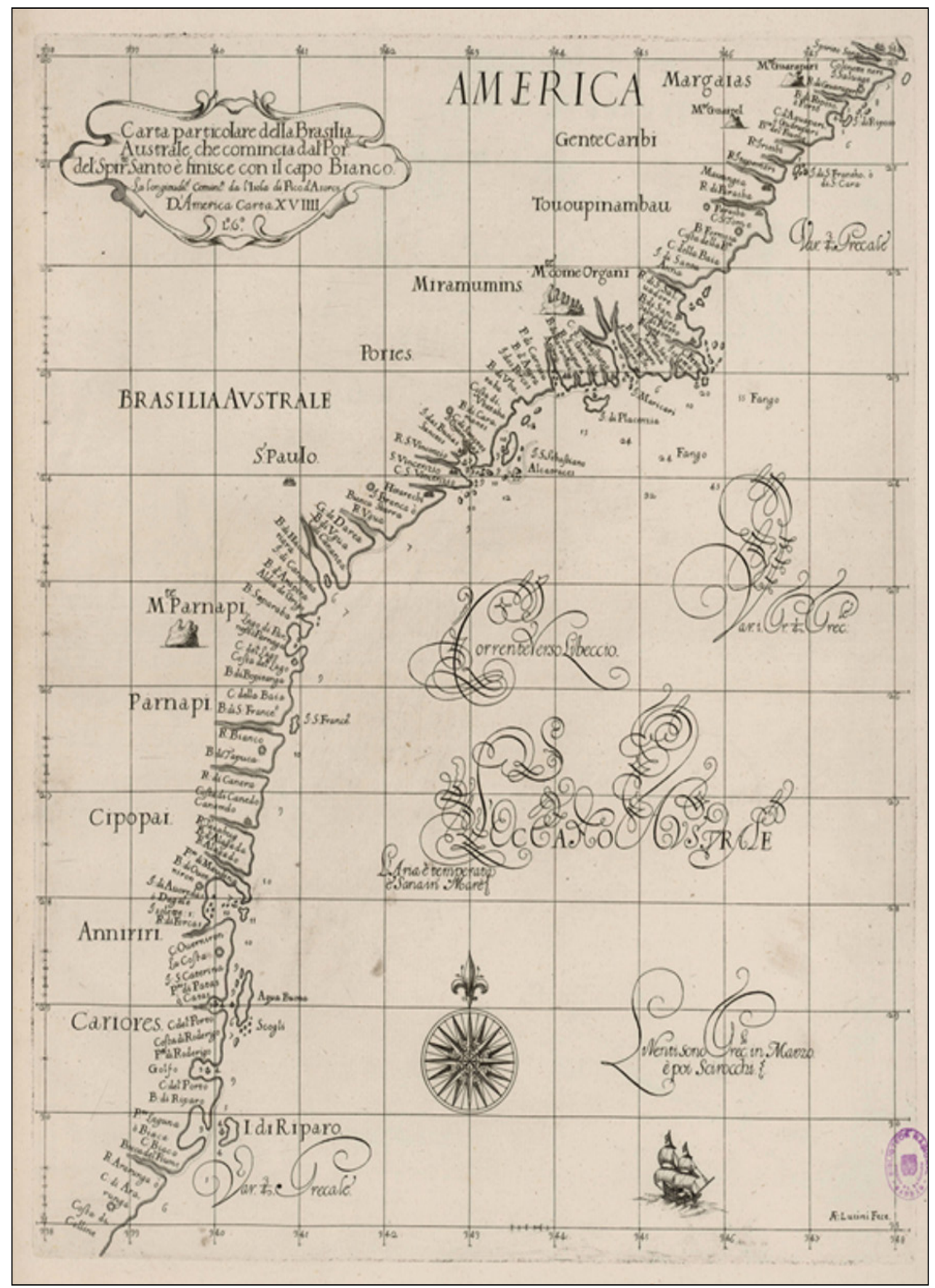


Figura 17 - Mapa do rio La Plata (6) (Dudley, 1661: 214)

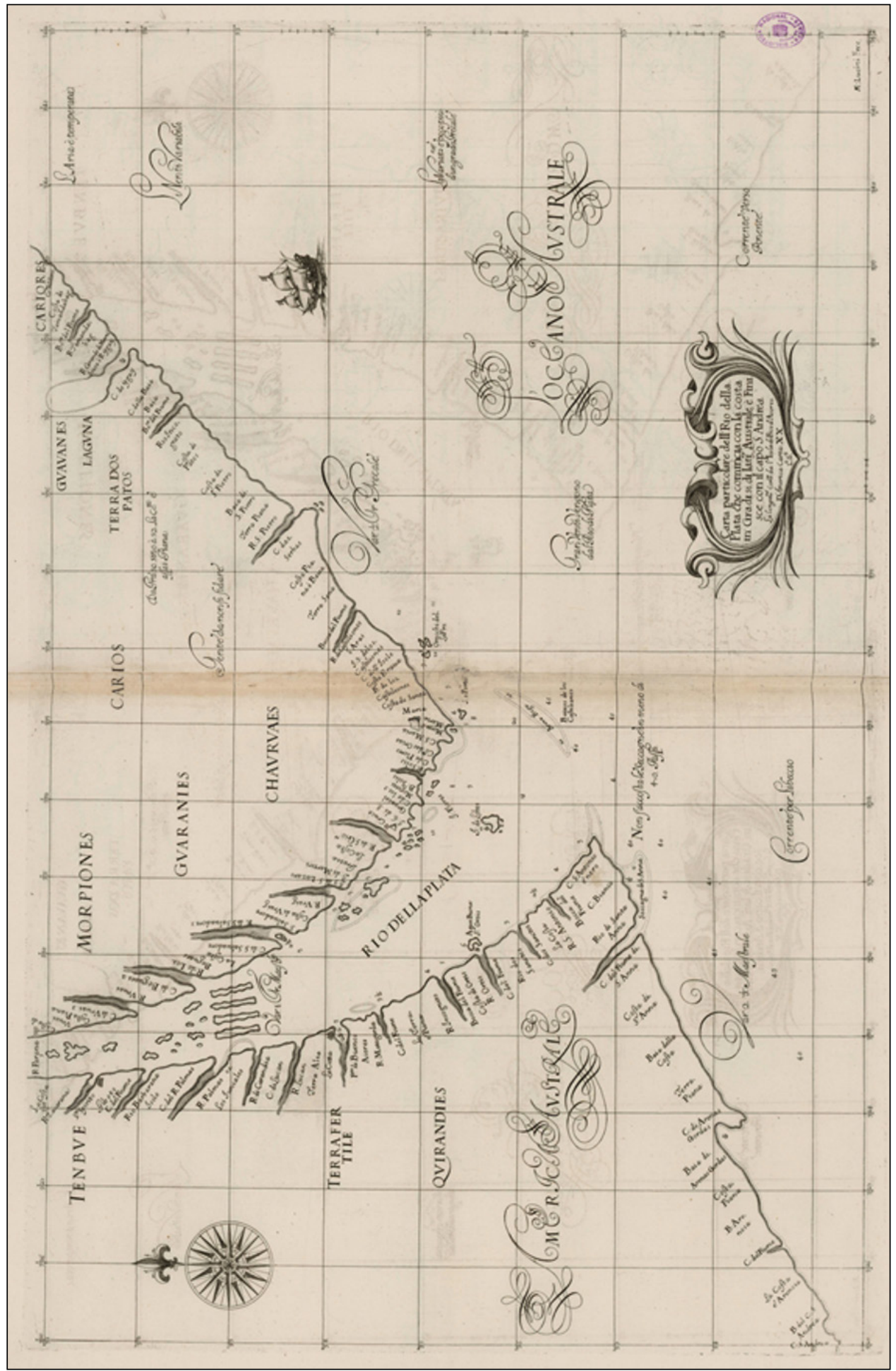


Dudley levou 12 anos para completar essa obra, gastando nela a soma de 5.000 libras de cobre.

Faleceu em 6 de setembro de 1649, na Villa Rinieri, nas cercanias de Florença e foi sepultado na Igreja de San Pancrazio daquela cidade.

Doze anos após sua morte foi publicada a segunda edição de sua obra magna (Dudley 1661) (Figura 18), agora em dois volumes. Houve um grande rearranjo do texto, com a inclusão de muitas adições, ao que se diz coligidas de manuscritos deixados pelo autor (Payne \& Foss 1842: 212).

É nessa edição, no segundo volume, que encontramos um pequeno vocabulário da língua Tupinambá, com 136 vocábulos ou frases curtas, que apresentamos facsimilarmente (Figuras 19-20), transcrevemos e damos uma lista corrigida com as traduções para o português.

\section{Vocabulário Tupinambá (Dudley 1661)}

Esse vocabulário foi simplesmente incluído na edição de 1661, sem nenhuma explicação ulterior. Como se poderá ver na sequência, utiliza aleatoriamente verbetes do capítulo XX (Colloque de l'entree ou arrivee en la terre du Bresil entre les gens du pays nommez Toupinambaoults \& Toupinenquin en langue Saunage \& Francois) de Jean de Léry (1578: 234-267), por vezes sem seguir ordem alguma, noutras copiando alguns verbetes de várias páginas em sequência. Dudley confundiu várias letras frequentes vezes (por exemplo, $n$ por $u$ e $r$ por $t$ ) e traduziu muito mal, para o italiano, muitas palavras.

Um erro introduzido por Dudley, ao citar Rothomagum como palavra tupi [sic] para "Vn villagio", indica ter ele utilizado a versão latina de Léry, pois o mesmo erro Rothomagum ao invés de Rothomagnum ocorre nessa edição (cf., p. ex., Léry 1594: 185: "ROTHOMAGVM, Vrbs quedam nominis"). Ver também "Toiotru" na nota 19.

Entretanto, citaremos abaixo os verbetes de Léry segundo a primeira edição francesa (Léry 1578).

\section{P. 35}

Seguono alcune parole della lingua migliore, e più generale della/ Brasiglia, le quali seruono per commerzio con le gentil Barbare della terra ferma di essa./

\begin{tabular}{|c|c|}
\hline Tupinambá & Tradução em italiano \\
\hline Erimen & Non sò \\
\hline Tourousson gaten & Principalmente \\
\hline Ioh & Sono pronto \\
\hline Escendoup & Ho sentito \\
\hline
\end{tabular}




\begin{tabular}{|c|c|}
\hline Mahmo & Molti \\
\hline Rothomagum $^{8}$ & Vn villagio \\
\hline Augepe & Vna cosa \\
\hline Toiotru & Vuol piouere \\
\hline $\mathrm{Pa}$ & Così stà \\
\hline Araip & L'aria è cattina \\
\hline Oicoegato & E lontano di quì \\
\hline
\end{tabular}

\section{P. 36}

\begin{tabular}{|c|c|}
\hline Tupinambá & Tradução em italiano \\
\hline Verap & Il tempo è oscuro \\
\hline Ita & Vna pietra \\
\hline Nembi & Vn orecchio. \\
\hline Mah & Il Cielo \\
\hline Shua & La fronte \\
\hline Conurassi & Il Sole \\
\hline Iasce & La Luna \\
\hline Che & Io \\
\hline Cheresse & Gli occhi \\
\hline Issitata miri & Le stelle del Cielo \\
\hline Chetin & Il naso \\
\hline Ibouy & La terra \\
\hline Porauen & Il mare \\
\hline Vhete & Acqua dolce \\
\hline Vhcen & L'acqua del mare \\
\hline Augebo & Son certo \\
\hline Agne he oach & Quel che dico, è vero \\
\hline Sti po que & Non parlo senza ocasione \\
\hline Marauo amo pe? & Perche lo domandi? \\
\hline Maeda & La fiamma del fuoco \\
\hline Setaque & Ci sono molti \\
\hline Cembere ingue & Aspetate più \\
\hline Arouan & Uno specchio \\
\hline Kuap & Vn pettine \\
\hline
\end{tabular}

\footnotetext{
${ }^{8}$ Um erro do autor. Deveria ser Rothomagnum, nome romano da cidade de Rouen.
} 


\begin{tabular}{|c|c|}
\hline Soo & Bestiame saluatico \\
\hline Oura & Gli vccelli \\
\hline Pira & Pesce \\
\hline Ouy & Farina \\
\hline Pinda & Lamo da pescare \\
\hline Montemonten $^{9}$ & Vn punterolo $^{10}$ \\
\hline Arrout & Gli ho hatto \\
\hline Guia par ete & Sono cose grande \\
\hline Marauae & Da quel, ch'io sono \\
\hline Auge gaton tega & Egli ha discorso molto bene \\
\hline Setape & Di molti \\
\hline Necri & Orsù \\
\hline Aaub & Vestiti \\
\hline Mabouy & Quanti siati \\
\hline Augebe & E bem detto \\
\hline Que & Il capo \\
\hline Voua & La faccia \\
\hline Chereburre & Il fratello minore \\
\hline Iuron & La boca \\
\hline Redimi va que & La barba \\
\hline Apelou & La lingua \\
\hline $\operatorname{Ram}$ & I denti \\
\hline Che aioeue & Il collo \\
\hline Poca & Il petto \\
\hline $\mathrm{De}$ & $\mathrm{Tu}$ \\
\hline Ahe & Egli, ò lui \\
\hline Orece & Noi \\
\hline Pee & Voi \\
\hline Auue & Quelli \\
\hline Emiredutata & Andate fuori \\
\hline Emegoeptata & Gli è segno del fuoco \\
\hline Emogiperu & Cette cose di pesce \\
\hline Esiessa & Togliete \\
\hline
\end{tabular}

${ }^{9}$ Léry (1578: 346): “Moutemõten des alaines".

${ }^{10}$ No italiano moderno punteruolo (lat. punctarius) $=$ furador, instrumento perfurante. 


\begin{tabular}{|c|c|}
\hline Coceri vpe & Và à bere della fonte \\
\hline Erot vichesai & Datemi dell'acqua \\
\hline Cherenue augepe & Datemi bere \\
\hline Querema sheremyourecoap & Datemi mangiare \\
\hline Tace poch & Lauateui le mani \\
\hline Che embouasi & Io ho sete \\
\hline Cherace & Io sudo \\
\hline Cheron & Sono fredo \\
\hline Cheracoup & Io ho lafebre \\
\hline Checaroe & Ne hò dolore \\
\hline Caroue & La notte, ò sera \\
\hline Cheroemp & Ne son'allegro \\
\hline Chere & Vn seruitore \\
\hline Querre maliau & E potente in guerra \\
\hline Cherop & Il padre \\
\hline Cherequeat & Il fratello maggiore \\
\hline Renudire & La sorella \\
\hline Tacout & Vengo, ò verrò \\
\hline Tipet & La figlia della sorella \\
\hline Aica & Vn'amica \\
\hline Chesì & La madre \\
\hline Sur & La matrigna \\
\hline Cheraijt & La figlia \\
\hline Ramemynon & Il nipote del nonno \\
\hline Aico & Io sono \\
\hline Ereuo & Voi siate, (cioè tu sei) \\
\hline Oico & Egli è \\
\hline Oreico & Noi siamo \\
\hline Peico & Voi siate \\
\hline Auree aico & Io son quì \\
\hline Aico ay aqueente & Allora sarò \\
\hline Acoire & Sarò per l'auuenire \\
\hline Tauge & Subito \\
\hline Taico deiron & Sono con voi \\
\hline Aiout & Io vengo \\
\hline Ereiout & Tu venisti \\
\hline
\end{tabular}




\begin{tabular}{|c|c|}
\hline Oout & Egli veniua \\
\hline Oreiout & Egli verrà \\
\hline Andeoout & Quelli sono venuti \\
\hline Aiout agoueme & Alora veniuano \\
\hline Aiout iran & Vengano \\
\hline Emoout & Faccia, che io possa venire \\
\hline Peorì & Venite \\
\hline Aiout mo & Vengo volentieri \\
\hline Enegouere & L'anima è vscita del corpo \\
\hline Ranggere & Il Demonio \\
\hline Tavvme & Egli verrà \\
\hline Inubya & $\begin{array}{c}\text { Vna cornetta all'vsãza } \\
\text { degl'Indiani }\end{array}$ \\
\hline Neui & Vi prego \\
\hline Ascoe & La gola \\
\hline Recape & La parte di dietro d'vn huomo \\
\hline Rousboni & Le reni \\
\hline Reuire & Le narici \\
\hline Inuan poni & Le spalle \\
\hline Inua & Le braccia \\
\hline Po & La mano \\
\hline Ponea & Le dita \\
\hline Puyac & Lo stomaco \\
\hline Poron asseu & Il bellico \\
\hline Cam & Le poppe d'vna donna \\
\hline Roduponam & Le ginocchia \\
\hline Pouy & Il piede \\
\hline Pussempi & L'vnghie delle dita de' piedi \\
\hline Ponempe & L'vnghie delle dita delle mani \\
\hline Gugeney & Il cuore \\
\hline Eney & L'anima, e spirito d'vn'huomo \\
\hline Recouen & $\begin{array}{c}\text { Le membra segrete d'vn'huomo, } \\
\text { ò d'vna Donna }\end{array}$ \\
\hline Aignen & $\begin{array}{l}\text { Vn Demonio particolare, ch'è } \\
\text { frequente à quegl'Indiani } \\
\text { saluatichi della Brasiglia }\end{array}$ \\
\hline
\end{tabular}




\section{CORREÇÕES DOS VOCÁBULOS E TRADUÇÃO EM PORTUGUÊS}

\begin{tabular}{|c|c|c|}
\hline Grafia original & Forma corrigida & Tradução em português \\
\hline Erimen $^{11}$ & Erimã & Não! \\
\hline Tourousson gaten $^{13}$ & Turuçúcatú & Muito grande \\
\hline Ieh $^{14}$ & Te & Estou pronto \\
\hline Escendoup $^{15}$ & Ecendúb & Ouça \\
\hline Mahmo $^{16}$ & Nãmo & São tantos \\
\hline Rothomagun $^{17}$ & & Um \\
\hline Augepe $^{18}$ & Ojepé & \\
\hline Toiotru $^{19}$ & & Sim (do homem) \\
\hline Pa $^{20}$ & Pa & Tempo (ou dia) ruim \\
\hline Araip $^{21}$ & Áraíb &
\end{tabular}

${ }^{11}$ Léry (1578: 343): “Erimen. Non, ou Nenny [como interjeição: "Não!”], página 353: "Erimem. Nenny" e página 364: “Erymen. Nenny". Rodrigues (2009: 247): "erimã, não, ou: de modo algum”, Rodrigues (2009: 253): “erimã, não”, Rodrigues (2009: 259): “erimã, não".

${ }^{12}$ In Silva (2011: 241).

${ }^{13}$ Léry (1578 : 363): “Touroussou-gatou. Elles [les maisons] sont fort grãdes”. Rodrigues (2009: 259): "turuçúcatú, são muito grandes".

${ }^{14}$ Léry (1578: 364): “Ieh. Me voila prest”. Rodrigues (2009: 260): "te, estou pronto".

${ }^{15}$ Léry (1578: 364): Escendou. Escouté”. Rodrigues (2009: 260): “ecendúb, escute”.

${ }^{16}$ Léry (1578: 363): "Mahmo. Beaucoup. Ce mot emporte plus que beaucoup car ils le prẽnent pour chose esmerueillable". Rodrigues (2009: 259): "nãmo, muito (esta palavra significa mais que muito, pois eles a usam para coisa admirável".

${ }^{17}$ Léry (1578: 361): "ROVEN [a Rothomagnum dos romanos!], C'est vne ville ainsi nommee. Tau-ouscou [sic]-pe-ouim. Est-ce vn grand village. Ils ne mettent point de difference entre ville et village à raison de leur vsage, car ils n'ont point de ville”. Rodrigues (2009: 258): "tábuçúpe uí, é essa uma aldeia grande? Eles não fazem diferença entre cidade e aldeia, de acordo com o seu uso, pois não têm cidades".

${ }^{18}$ Léry (1594: 271): “Auge-pe. Vn seulement”. Rodrigues (2009: 258): “ojepé, um só”.

19 Provavelmente seja TONITRUO (trovão). Na edição latina (Léry 1694: 284) temos: "Amen. Pluuia. Amen poutou. Tempestas pluuia ingruente. Toup-en. Tonitruo: toupé Verap: est corruscatio". E na francesa (Léry 1578: 359): “Amen, pluye; Amen poyton, le temps disposé \& prest à pleuuoir. Toupen, tonnerre, Toupen verap, c'est l'esclaire qui la preuient". Rodrigues (2009: 257): "amán, chuva; amãpytún, tempo disposto e pronto para chover; tupán, trovão; tupãberáb, o relâmpago que precede o trovão".

${ }^{20}$ Léry (1578: 341 e 362): “Pa. Ouy”. Rodrigues (2009: 259): “pá, sim”.

${ }^{21}$ Léry (1578: 359): “Arraip, mauuais air”. Rodrigues (2009: 257): “áraíb, mau ar”. 


\begin{tabular}{|c|c|c|}
\hline Oicoegato $^{22}$ & Oicoé catu & É muito diferente \\
\hline Verap $^{24}$ & (Tupã)beráb & Relâmpago \\
\hline Ita $^{25}$ & Itá & Pedra \\
\hline Nembi $^{26}$ & Nambí & Orelha \\
\hline Mah $^{27}$ & Ybác & Céu \\
\hline Shua $^{28}$ & Cybá & Fronte \\
\hline Conurassi $^{29}$ & Cuaracý & Sol \\
\hline Iasce $^{30}$ & Iacý & Lua \\
\hline Che $^{31}$ & Xeé & Eu \\
\hline Cheresse $^{32}$ & Xereçá & Meu olho \\
\hline Issitata miri $^{33}$ & Iacýtatá mirĩ & Estrelinhas \\
\hline
\end{tabular}

${ }^{22}$ Léry (1578: 363): “Oicoe-gatou. Il y a une grande difference”. Rodrigues (2009: 259): “oicó'écatú, há grande diferença (são bem diferentes)".

${ }^{23}$ Oicó 'pecatú in Silva (2011: 253).

${ }^{24}$ Léry (1578: 359): “Toupen verap, c'est l'esclair qui le preuient”. Rodrigues (2009: 257): “tupãberáb, o relâmpago que precede o trovão".

${ }^{25}$ Léry (1578: 359): "Ita, est proprement pris pour pierre. Aussi est prins pour toute espece de metal \& fondement d'edifice, come aoh-ita, le pillier de la maison". Rodrigues (2009: 257): "itá, é principalmente usado para pedra; também é usado para toda espécie de metal e fundamento de edifício, como Aoh-ita (óc-ytá), o pilar da casa".

${ }^{26}$ Léry (1578: 364): “Che-nembi. Mes oreilles”. Rodrigues (2009: 260): “xé nambí, minhas orelhas".

${ }^{27}$ Léry 1578 : 359): “Mac, Le ciel”. Rodrigues (2009: 257): “ybác, céu”.

${ }^{28}$ Léry (1578: 364): “Chèsshua. Mon front”. Rodrigues (2009: 257): “xé cybá, minha testa”.

${ }^{29}$ Dudley provavelmente leu erroneamente essa palavra; deveria ser Couarassi. Em Léry (1578: 359): “Couarassi, le Soleil”. Rodrigues (2009: 257): “cuaracý, sol”.

${ }^{30}$ Léry (1578: 359): “Iasce, la Lune”. Rodrigues (2009: 257): “jacý, lua”.

${ }^{31}$ Léry (1578: 364): “Ché, C'est la premiere personne du singulier qui sert en toute maniere de parler, tant primiyiue que deriuatiue, possessiue, ou autrement. Et les autres personnes aussi". Rodrigues (2009: 260): "xé, é a primeira pessoa do singular, que serve em toda maneira de falar, tanto primitiva, como derivativa, possessiva ou outra. $\mathrm{E}$ as outras pessoas também". Rodrigues (2009: 262): "xé, eu".

${ }^{32}$ Léry (1578: 365): “Ché-ressa. Mes yeux”. Rodrigues (2009: 260): “xé reçá, meus olhos”.

${ }^{33}$ Léry (1578: 359): "Iassi tatá miri, Ce sont toutes les autres petites estoilles". Rodrigues (2009: 257): “jacýtatámirĩ, são todas as outras estrelas pequenas”. Léry contrapôs essa expressão a "iassi tatá ouassou; La grande estoille du matin \& du vespre qu'on appelle cõmunémẽt Lucifer”. Rodrigues (2009: 257): “jacýtatáguaçú, a grande estrela da manhã e da tarde, que chamamos comumente Lúcifer". 


\begin{tabular}{|c|c|c|}
\hline Chetin $^{34}$ & Xetĩ & Meu nariz \\
\hline Ibouy $^{35}$ & Ybý & Terra \\
\hline Porauen $^{36}$ & Paranã & Mar \\
\hline Vhete $^{37}$ & Yeté & Água verdadeira(doce) \\
\hline Vhcen $^{38}$ & Yceẽ & Água salgada \\
\hline Augebo $^{39}$ & Aujébe & Está bem \\
\hline Agne he oach ${ }^{40}$ & Anhetégué & É bem verdade! \\
\hline Sti po que $\mathrm{e}^{41}$ & Aipónhé & É isso! \\
\hline Marauo amo pe ${ }^{42}$ & Marãnamopé & Por que? \\
\hline Maeda $^{43}$ & Maeendý & A chama do fogo \\
\hline Setaque $^{44}$ & Cetá nhé & Há muitos \\
\hline Cembere ingue $^{45}$ & Enhãbé ranhé & Espera um pouco \\
\hline Arouan $^{46}$ & Aruá & Espelho \\
\hline Kuap $^{47}$ & Kyguáb & Pente \\
\hline $\mathrm{Soo}^{48}$ & Soó & Animal(de caça) \\
\hline
\end{tabular}

${ }^{34}$ Léry (1578: 365): “Ché-tin. Mon nez”. Rodrigues (2009: 260): “xé tĩ, meu nariz”. ${ }^{35}$ Léry (1578: 359): “Ybouy c'est la terre”. Rodrigues (2009: 257): “ybý, é a terra”.

${ }^{36}$ Provavelmente um erro de Dudley por paranen. Em Léry (1578: 359): “Paranan la mer". Rodrigues (2009: 257): “paraná, mar".

${ }^{37}$ Léry (1578: 359): “Uh-etè c'est eau douce”. Rodrigues (2009: 257): “'ýeté, água doce”. ${ }^{38}$ Léry (1578: 359): “Uh-een eau salee”. “Ýe’ẽm, água salgada”.

${ }^{39}$ Ver nota 15.

${ }^{40}$ Léry (1578: 345): “Augé-terah. Voila qui est bien”. Rodrigues (2009: 248): “aujé tetiruã, está bem".

${ }^{41}$ Léry (1578: 353): “Aipo-gué. Ie le di pour cause”. Rodrigues (2009: 252): “aipo nhẽ, eu o digo por dizer (isso simplesmente)".

${ }^{42}$ Léry (1758: 353): “Marã amo pè? Pouquoy t'en enquiers tu”. Rodrigues (2009: 252): "marãnamope, por que você pergunta? (por quê?)".

${ }^{43}$ Léry (1578: 351): “Mae du. Qui est flãbe de feu de quelque chose". Rodrigues (2009: 251): "ma'éendy, que é a chama de fogo de alguma coisa".

${ }^{44}$ Léry (1578: 350): “Seta-gue, Il y en a beaucoup”. Rodrigues (2009: 251): “cetá nhẽ, há muitos".

${ }^{45}$ Léry (1578: 346): “Eémbereingué, Atten encore”. Rodrigues (2009: 248): “enhambé ranhẽ, espere ainda".

${ }^{46}$ Léry (1578: 346): “Arroua des miroirs”. Rodrigues (2009: 248): “guaruguá, espelhos”.

${ }^{47}$ Léry (1578: 346): “Kuap des peignes”. Rodrigues (2009: 248): “kyguáb, pentes”.

${ }^{48}$ Léry (1578: 347): “Soo, Des bestes”. Rodrigues (2009: 249): “so’ó, animais”. 


\begin{tabular}{|c|c|c|}
\hline Oura $^{49}$ & Guyrá [uyrá] & Ave \\
\hline Pira $^{50}$ & Pirá & Peixe \\
\hline Ouy $^{51}$ & Uí & Farinha \\
\hline Pinda $^{52}$ & Pindá & Anzol \\
\hline Montemonten $^{53}$ & Mutúmutúca & Sovela, furadores \\
\hline Arrout $^{54}$ & Arút & Eu trouxe \\
\hline Guia par ete $^{55}$ & ybyrapáreté & Arco verdadeiro \\
\hline Maravae $^{56}$ & Marãbaé & Qual? \\
\hline Auge gaton tega $^{57}$ & Aujé catú tenhé & Está muito bem \\
\hline Setape $^{58}$ & Cetá pe & São muitos? \\
\hline Necri & Neĩ corí & Ora vamos logo! \\
\hline Aaub $^{59}$ & Aóba & Roupa \\
\hline Mabouy $^{60}$ & Mobýr & Quantos? \\
\hline Augebe $^{61}$ & Ojepé & Um \\
\hline
\end{tabular}

${ }^{49}$ Léry (1578: 347): “Oura, des oiseaux”. Rodrigues (2009: 249): “guyrá, aves”.

${ }^{50}$ Léry (1578: 347): “Pira, du poisson”. Rodrigues (2009: 249): “pirá, peixe”.

${ }^{51}$ Léry(1578: 347): “Ouy, de la farine”. Rodrigues (2009: 249): “u'í, farinha”.

${ }^{52}$ Léry (1578: 346): "Pinda Des haims". Rodrigues (2009: 248): "pindá, anzóis".

${ }^{53}$ Léry (1578: 346): “Moutemõton des aleines”. Rodrigues (2009: 248): “mutúmutúca, sovelas (brocas)".

${ }^{54}$ Léry (1578: 345): “Arrout, Ie’n ay apporté”. Rodrigues (2009: 248): “arúr, trouxe”.

${ }^{55}$ Léry (1578: 359): “Ourapat, vn arc. Et neantmoins que ce soit vn nom cõposé de ybouyrah qui signifie bois, \&apart crochu, ou partie toutesfois ils prononcent Orapat par syncope". Rodrigues (2009: 257): "urapár, arco. Embora este seja um nome composto de ybourah (ybyrá), que significa pau, e apat (apár), recurvo, no entanto eles pronunciam Orapat (urapár) por síncope".

${ }^{56}$ Léry (1578: 343): “Mara vaé? De quelle sorte ou couleur?” e página 344: "Mara vaê? Quels sont ils?”. Rodrigues (2009: 247): “marãba'épe, quais são?”, Rodrigues (2009: 259): “marãba'épe, como são elas?".

57 Léry (1578: 344): “Augé-gatou-tégué. Voila tresbien dit”. Rodrigues (2009: 247): "aujécatú tenhë, está muito bem dito".

${ }^{58}$ Léry (1578: 343): “Seta-pé? Beau-coup?”. Rodrigues (2009: 246): “cetápe, muitos?”.

${ }^{59}$ Léry (1578: 342): “A-aub. des vestements”. Rodrigues (2009: 246): “aóba, roupas”.

${ }^{60}$ Léry (1578: 342): “Mobouy? Combien?”. Rodrigues (2009: 246): “mobype, quantas?”.

${ }^{61}$ Pela sequência, deve ser Augé-pé, o número 1 (Léry 1578: 342), Rodrigues (2009: 246):

“ojepé, 1"; e na página 361: “Auge-pe. Vn seulement". 


\begin{tabular}{|c|c|c|}
\hline Que $^{62}$ & Ába & $\begin{array}{c}\text { Cabelo [erradamente como } \\
\text { cabeça em Dudley] }\end{array}$ \\
\hline Voua $^{63}$ & Obá & Rosto \\
\hline Chereburre $^{64}$ & Xerybýra & Meu irmão caçula \\
\hline Iuron $^{65}$ & Jurú & Boca \\
\hline Redimi va que $^{66}$ & Rendybá ába & Barba \\
\hline Apelou $^{67}$ & Apecũ & Língua \\
\hline Ram $^{68}$ & Rãnh(a) & Dente \\
\hline Che aioeue $^{69}$ & Xeajúra & Meu pescoço \\
\hline Poca $^{70}$ & Potiá & Peito \\
\hline De $^{71}$ & Ndé & Tu \\
\hline Ahe $^{72}$ & Aé & Ele, ela \\
\hline Orece $^{73}$ & Orée & Nós \\
\hline
\end{tabular}

62 Léry (1578: 364): “Chè-aue. Mon chef ou mon cheueux”. Rodrigues (2009: 260): “xé 'ába, minha cabeça ou cabelos".

${ }^{63}$ Léry (1578: 364): “Ché-voua. Mon visage". Rodrigues (2009: 260); "xé robá, meu rosto". ${ }^{64}$ Léry (1758: 369): “Che-rebure. Mon puisné”. Rodrigues (2009: 263): “xé rýra, meu irmão mais moço".

${ }^{65}$ Léry (1578: 365): “Chè-iourou. Ma bouche”. Rodrigues (2009: 260): "xé juru, minha boca". ${ }^{66}$ Léry (1578: 365): “Chè-redmiua-aué. Ma barbe”. Rodrigues (2009: 260): “xé rendybáába, minha barba".

${ }^{67}$ Léry (1578: 365): “Ché-ape-cou. Ma langue”. Rodrigues (2009: 160): “xé apecũ, minha língua".

${ }^{68}$ Léry (1578: 365): “Chè-ram. Mes dents”. Rodrigues (2009: 260): “xé rãnha, meus dentes".

${ }^{69}$ Léry (1578: 365): “Ché-aiouré. Mon col ou ma gorge”. Rodrigues (2009: 260): “xé ajúra, meu pescoço ou minha garganta".

${ }^{70}$ Léry (1578: 365): “Ché-poca. Ma poitrine”. Rodrigues (2009:260): “ xé potiá, meu peito".

${ }^{71}$ Léry (1578: 366 [erroneamente impresso como “352”]): “Dè. toy”. Rodrigues (2009: 262): "ndé, você".

${ }^{72}$ Léry (1578: 366 [erroneamente impresso como "352"]): “Ahé. luy. Quant à la tierce personne du singulier ahe est masculin \& pour le feminin \& neutre aé sans aspiration". Rodrigues (2009: 262): "ahẽ, ele. Quanto à terceira pessoa do singular, ahe (ahẽ) é masculino, e para o feminino e neutro aé (a'é) sem aspiração".

${ }^{73}$ Léry (1578: 366 [erroneamente impresso “352”]): “Oree. Nous”. Rodrigues (2009: 262): "oré, nós". 


\begin{tabular}{|c|c|c|}
\hline Pee $^{74}$ & Peẽ & Vocês \\
\hline Auue $^{75}$ & Auã & Eles \\
\hline Emiredutata $^{76}$ & Emoendýtatá & Acenda o fogo \\
\hline Emegoeptata $^{77}$ & Emoguéb tatá & Apaga o fogo! \\
\hline Emogi peru $^{78}$ & Emojýb pirá & Cozinhe o peixe \\
\hline Esiessa $^{79}$ & Ececýr & Asse-o \\
\hline Coceri vpe $^{80}$ & Ecuái ýpe & Vá à fonte \\
\hline Erot vi chesai $^{81}$ & Erúr y xeuséi & $\begin{array}{c}\text { Traze água, } \\
\text { tenho sede }\end{array}$ \\
\hline Cherenue augepe $^{82}$ & Xe... ojepé & Dá-me de beber \\
\hline $\begin{array}{c}\text { Querema } \\
\text { sheremyourecoap }\end{array}$ & $\begin{array}{c}\text { Keremé } \\
\text { xeremiúerocuáb }\end{array}$ & $\begin{array}{c}\text { Depressa, passe-me } \\
\text { a comida }\end{array}$ \\
\hline Tace poch & \\
\hline
\end{tabular}

${ }^{74}$ Léry (1578: 366 [erroneamente impresso “352”]): “Peè. Vous”. Rodrigues (2009: 262): "pe'ẽ, vocês".

${ }^{75}$ Léry (1578: 366 [erroneamente impresso “352”]): “Au-aé. Eux. Et au pluriel $A u$-ae est pour les deux genres tant masculins que feminins: \& par consequent peut estre commun". Rodrigues (2009: 262): "auã aé, eles. E no plural $A u$-aé (auã aé) é para os dois gêneros, tanto masculino quanto feminino e, portanto, pode ser comum".

${ }^{76}$ Léry (1578: 367): “Emiredu-tata. Allume le feu”. Rodrigues (2009: 262): “eimoený tatá, acenda o fogo".

${ }^{77}$ Léry (1578: 367): “Emo-goep tatá. Estein le feu”. Rodrigues (2009: 262): “eimoguéb tatá, apague o fogo".

${ }^{78}$ Léry (1578: 367): “Emogip-pira. Fay cuire le poisson”. Rodrigues (2009: 262): “eimojýb pirá, faça cozer o peixe".

${ }^{79}$ Léry (1578: 367): “Essessit. Rosti-le”. A grafia apresentada por Dudley difere muito da de Léry, mas essa palavra vem na mesma sequência da obra do autor francês. Rodrigues (2009: 262): "esesýr, asse-o".

${ }^{80}$ Léry (1578: 367): “Coein vpé. Va à la fontaine”. Rodrigues (2009: 262): “ecuáí 'ýpe, vá à fonte (vá ao rio)".

${ }^{81}$ Léry (1578: 367): “Erout-v-ichesue. Apporte moy de l'eau”. Rodrigues (2009: 262): "erúr 'ý ixébe, traga-me água".

${ }^{82}$ Léry (1578: 367): “Ché-renni-auge-pe. Donne moy à boire”. Rodrigues (2009: 262): “xé re'ým jepé, dê-me de beber".

${ }^{83}$ Léry (1578: 367): “Quere-me-che-remyou-recoap. Viẽ moy donner à manger”. Rodrigues (2009: 262): "keremé xé remi’úerocuáb, venha dar-me de comer (depressa, passe-me a comida)".

${ }^{84}$ Léry (1578: 367): “Taie-poeh. Que ie laue mes mains”. Rodrigues (2009: 262): “tajepoéi, que eu lave as mãos"). 


\begin{tabular}{|c|c|c|}
\hline Che embouasi $^{85}$ & Xeambyasý & Estou com fome \\
\hline Cherace $^{86}$ & Xeryái & Suo \\
\hline Cheron $^{87}$ & Xeroý & Estou com frio \\
\hline Cheracoup $^{88}$ & Xeracúb & Tenho febre \\
\hline Checaroe $^{89}$ & Xecarucacý & Estou triste, saudoso \\
\hline Caroue $^{90}$ & Carúca & Noite, tarde \\
\hline Cheroemp $^{91}$ & Xerorýb & Estou alegre \\
\hline Chere $^{92}$ & Xeremimbuáia & Um criado (servidor) \\
\hline Querre maliau $^{93}$ & Kyreymbába & Valente \\
\hline Cherop $^{94}$ & Xerúb & Meu pai \\
\hline Cherequeat $^{95}$ & Xerykeýr & Meu irmão mais velho \\
\hline Renudire $^{96}$ & Rendýra & Irmã \\
\hline Tacout $^{97}$ & Taiúr & Que eu venha \\
\hline
\end{tabular}

${ }^{85}$ Léry (1578: 367): “Ché emboassi. I'ay faim de manger”. Rodrigues (2009: 262): “xé ambyacý, tenho fome".

${ }^{86}$ Léry (1578: 367): “Ché-reaic. I'ay chaud, ie sue”. Rodrigues (2009: 262): “xé ryái, tenho calor, suo".

${ }^{87}$ Léry (1578: 367): “Chè-roü. I'ay froid”. Rodrigues (2009: 262): "xé ro'ý, tenho frio".

${ }^{88}$ Léry (1578: 367): “Ché-racoup. I'ay la fieure”. Rodrigues (2009: 262): “xé racúb, tenho febre".

${ }^{89}$ Incompleto em Dudley. Em Léry (1578: 367) lemos: "Ché-carouc-assi. Ie suis triste". Rodrigues (2009: 263): "xé carucacý, estou triste (estou saudoso). Apesar de carouc (carúc) significar a tarde".

${ }^{90}$ Léry (1578: 367): "Neantmoins que carouc signifie le vespre ou le soir" (Apesar de carouc (carúc) significar a tarde”). (Referência à expressão Ché-carouc-assi).

${ }^{91}$ Léry (1578: 368): “Cheroemp. Ie suis ioyeux”. Rodrigues (2009: 263): “xé rorýb, estou alegre".

${ }^{92}$ Incompleto em Dudley. "Mon seruiteur". Rodrigues (2009: 263): “xé reimimbuáia, meu escravo".

${ }^{93}$ Léry (1578: 368): “Querre-mubau. Vn puissant en la guerre \& qui est vaillãt à faire quelque chose”. Rodrigues (2009: 263): "kyre'ymbába, um poderoso na guerra e que é valente para fazer qualquer coisa".

${ }^{94}$ Léry (1578: 368): “Chè-roup. Mon pere”. Rodrigues (2009: 263): "xé rúb, meu pai”.

${ }^{95}$ Léry (1578: 369): “Chè-requeyt. Mon frère aisné”. Rodrigues (2009: 263): "xé ryke’ýr, meu irmão mais velho".

${ }^{96}$ Léry (1578: 369): “Chè-renadire. Ma soeur”. Rodrigues (2009: 263): “xé rendýra, minha irmã".

${ }^{97}$ Léry (1578: 375): “Ta-iout, Que ie vienne”. Rodrigues (2009: 267): “jajúr, que eu venha”. 


\begin{tabular}{|c|c|c|}
\hline Tipet $^{98}$ & Ietipér & Filha da irmã \\
\hline Aica $^{99}$ & Aixé & Tia \\
\hline Chesì $^{100}$ & Xecý & Minha mãe \\
\hline Sur $^{101}$ & Cyýr & Madrasta \\
\hline Cheraijt $^{102}$ & Xerajýr & Minha filha \\
\hline Ramemynon $^{103}$ & Remiminõ & Neto \\
\hline Aico $^{104}$ & Aicó & Eu sou \\
\hline Ereuo $^{105}$ & Ereicó & Tu és \\
\hline Oico $^{106}$ & Oicó & Ele é \\
\hline Oreico $^{107}$ & Oroicó & Nós somos \\
\hline Peico $^{108}$ & Peicó & Vós sois \\
\hline Auree aico & Auãaé oicó & Eles são \\
\hline Aico ay aquente & Aicó acuéime & Eu estava então \\
\hline
\end{tabular}

${ }^{98}$ Léry (1578: 369): “Chè-tipet. La fille de ma soeur”. Rodrigues (2009: 264): “xé jetipér, a filha de minha irmã”.

${ }^{99}$ Léry (1578: 369): “Chè-aiché. Ma tante”. Rodrigues (2009: 264): “xé aixé, minha tia". ${ }^{100}$ Léry (1578: 369): “Ai. Ma mere. On dit aussi Ché-si ma mere \& le plus souuent en parlant d'elle”. Rodrigues (2009: 264): “a'í, minha mãe. Diz-se também Ché-si (xé sý), minha mãe, e mais frequentemente quando se fala dela".

${ }^{101}$ Léry (1578: 369): “Ché-siit, La compagne de ma mere qui est femme de mon pere comme ma mere". Rodrigues (2009: 264): "xé sy’ýr, a companheira de minha mãe, que é mulher de meu pai com minha mãe".

${ }^{102}$ Léry (1578: 369): “Chè-raiit. Ma fille”. Rodrigues (2009: 264): “xé rajýr, minha filha”. ${ }^{103}$ Léry (1578: 369): “Chérememynou. Les enfants de mes fils \& de mes filles”. Rodrigues (2009: 264): "xé rymyminõ, os filhos de meus filhos e de minhas filhas".

${ }^{104}$ Léry (1578: 369): “Aico. Ie suis”. Rodrigues (2009: 264): “aicó, eu estou”.

${ }^{105}$ Léry (1578: 369): “Ereico, Tu es”. Rodrigues (2009: 264): “ereicó, você está”.

${ }^{106}$ Léry (1578: 369): “Oico. Il est. La tierce personne du singulier \& plurier sont semblables, excepté qu'il faut adiouster au plurier an-ae pronõ, qui signifie eux aussi qu'il appert”. Rodrigues (2009: 264): “oicó, ele está. As terceiras pessoas do singular e do plural são semelhantes, salvo que é preciso acrescentar ao plural na ae (auãaé), pronome que significa eles, como se vê".

${ }^{107}$ Léry (1578: 370): “Oroico. Nous sommes”. Rodrigues (2009:264): “oroicó, nos estamos”. ${ }^{108}$ Léry (1578: 370): “Peico, Vous estes”. Rodrigues (2009: 264): “peicó, vocês estão".

${ }^{109}$ Léry (1578: 370): “Auraè oico, Ils sont”. Rodrigues (2009: 264): “auãaé oicó, eles estão”. ${ }^{110}$ Léry (1578: 370) traz "Plurier imparfait. Oroico aquoémè. Nous estions alors. Peico aquoémé. Vous estiez alors. Aurae-oico-aquoèmé. Ils estoient alors". Na tradução de Dudley o tempo verbal está no futuro, mas diz Léry (1578: 371): "Pour le temps à venir que l'on appelle Futur. Aico-irén, Ie seray pour l'auenir. Et en ensuyuant des autres personnes 


\begin{tabular}{|c|c|c|}
\hline Acoire $^{111}$ & Aicó irã & Eu serei \\
\hline Tauge $^{112}$ & Taujé & Basta! \\
\hline Taico deiron $^{113}$ & Taicó ndeirũ & Que eu esteja contigo \\
\hline Aiout $^{114}$ & Aiúr & Eu vim \\
\hline Ereiout $^{115}$ & Ereiúr & Tu vieste \\
\hline Oout $^{116}$ & Oúr & Ele veio \\
\hline Oreiout $^{117}$ & Oroiúr & Nós viemos \\
\hline Andeoout $^{118}$ & Auãaé oúr & Eles vieram \\
\hline Aiout agoueme & Aiúr acuéime & Eu vinha então \\
\hline
\end{tabular}

comme deuant, tant au singulier qu'au plurier". Rodrigues (2009: 264): “aicó acuéime, nós estávamos então. Peico quoémé (peicó acuéime), vocês estavam então. Aurae-oicoaquoémé (auãaé oicó acuéime), eles estavam então".

${ }^{111}$ Léry (1578: 371): "Pour le temps à venir que l'on appelle Futur. Aico-irén, Ie seray pour l'auenir. Et en ensuyuant des autres personnes comme deuant, tant au singulier qu'au plurier". Rodrigues (2009: 264): "para o tempo por vir, que chamamos futuro: Aico-irén (aicó irã), eu estarei no futuro. E fazendo-se seguir das outras pessoas como acima, tanto no singular como no plural".

${ }^{112}$ Léry (1578: 173): "Que si au contraire il ne luy plaisoit pas, \& qu'on ne luy eust riẽ voulu bailler, si tost qu'elle auoit dit vn peu rudement à cest oiseaux Augé, c'est à dire cesse... [nossa ênfase] e Léry (1578: 371): “Toroico. Que nous soyons. Tapeico. Que vous soyez. Aurae-toico. Qu'ils soyent. Et pour le Futur il ne faut qu'adiouster Iren ainsi que deuant. Et si en commandant pour le present. Il faut dire Taugé, qui est à dire tout maintenant". Rodrigues (2009: 265): “toroicó, que nós estejamos. Tapeico (tapeicó), que vocês estejam. Aurae toico (auãaé toicó), que eles estejam. E para o futuro, basta acrescentar Iren (irã), como acima. E dando ordem para o presente, deve-se dizer Taugé (taujé), que quer dizer 'agora mesmo"'.

${ }^{113}$ Léry (1578: 372): "Taico-de-iron. Que ie soye auec toy \& ainsi des semblables". Rodrigues (2009: 265): "taicó ndé irũmo, que eu esteja com você”.

${ }^{114}$ Léry (1578: 373): “Aiout. Ie viens, ou ie suis venu”. Rodrigues (2009: 266): “ajúr, eu venho ou eu vim".

${ }^{115}$ Léry (1578: 373): “Ereiout. Tu viens, ou es venu”. Rodrigues (2009: 266): erejúr, você vem ou veio".

${ }^{116}$ Léry (1578: 373): “O-out. Il vient, ou est venu”. Rodrigues (2009: 266): “oúr, ele vem ou veio".

117 Léry (1578: 373): “Ore-iout. Vous venez, ou estes venus”. Rodrigues (2009: 266): “orojúr, nós vimos ou viemos".

${ }^{118}$ Léry (1578: 373): “An-ae-o-out. Viennent, ou sont venus”. Rodrigues (2009: 266): “auãé oúr, eles vêm ou vieram”.

119 Léry (1578: 373): “Aiout-aguoème. Ie venoye alors”. Rodrigues (2009: 266): “Ajúr acuéime bé, eu vinha então”. 


\begin{tabular}{|c|c|c|}
\hline Aiout iran $^{120}$ & Aiúrirã & Eu virei \\
\hline Emoout $^{121}$ & Emoúr & Faça vir \\
\hline Peorì $^{122}$ & Pejóri & Venham \\
\hline${\text { Aiout } \text { mo }^{123}}^{\text {Enegouere }}{ }^{124}$ & Aiúrmo & Eu viria \\
\hline Ranggere $^{125}$ & Angoéra & Alma fora do corpo \\
\hline Tavvme $^{126}$ & Anhangoéra & Demônio \\
\hline Inubya $^{127}$ & Túreme & Vindo ele \\
\hline
\end{tabular}

${ }^{120}$ Léry (1578: 373): “Aiout-Iran-nè. Ie viendrai vn certain iour aussi on peut dire Iran sans y adiouster, né, ains comme la phrase ou maniere de parler le requiert". Rodrigues (2009: 266): “ajúr irãne, eu virei algum dia; também se pode dizer Iran (irã), sem acrescentar nè (ne), conforme o requeira a frase ou maneira de falar".

${ }^{121}$ Léry (1578: 374): “Emo-out. Fay le venir”. Rodrigues (2009: 267): “eimoúr, faça-o vir”.

${ }^{122}$ Léry (1578: 374): “Pe-ori. Venez”. Rodrigues (2009: 267): “pejóri, venham vocês”.

${ }^{123}$ Léry (1578: 374): “Aiout-mo. Ie voudrois ou serois venu volontiers. Em poursuyãt les personnes comme en la declinaison de l'Indicatif. Il a vn temps à venir, em adioustant l'Aduerbe, comme dessus". Rodrigues (2009: 267): "ajúrmo, eu viria ou teria vindo de bom grado, seguindo as pessoas como na declinação do indicativo. Ele tem um tempo futuro, acrescentando o advérbio, como acima".

${ }^{124}$ Léry (1578: 366): "Che-enc-gouere, Mon ame apres quelle est sortie de mon corps". Rodrigues (2009: 261): “xé ánguéra, minha alma depois que ela saiu de meu corpo".

${ }^{125}$ Léry (1578: 263): "Surquoy ie diray que ces poures gens durant leurs vies sont aussi tellement affligez de ce malin esprit [Aygnan] (lequel autrement ils nomment Kaaguerre)...".

${ }^{126}$ Léry (1578: 375): “Touume. Venant”. Rodrigues (2004: 267): “túreme, vindo”.

${ }^{127}$ Léry (1578: 375): “Inuby-a. Des cornets de bois dont les Sauuages cornent”. Em Léry (1578: 227) lê-se também:

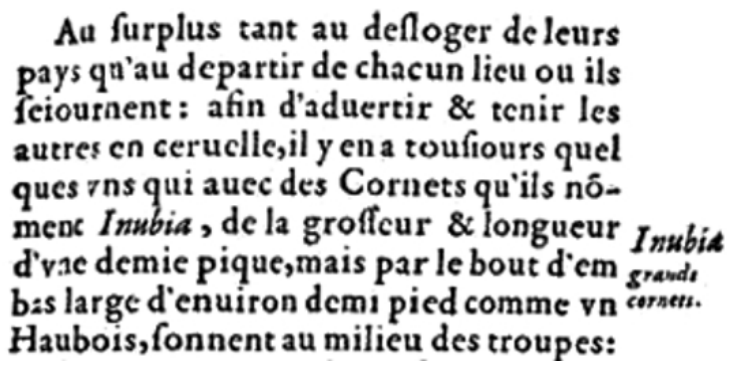

Ou, na tradução (muito livre) de Sérgio Milliet (in Léry, 1980: 187):

"Tanto no momento da partida como ao levantar acampamento onde pousam, surgem indivíduos armados de cornetas da grossura de um oboé e de quase um pé e meio de largura na extremidade inferior, a que chamam inybia* (*Aqui Plínio Ayrosa inseriu a seguinte nota de rodapé: 'Em obediência à prosódia francesa deveríamos grafar, com mais correção, inybiá. A corneta, tal como a referida por Léry, era chamada mimbyapá, isto é, instrumento 


\begin{tabular}{|c|c|c|}
\hline Neui $^{128}$ & Neĩ & Ora, vamos \\
\hline Ascoe $^{129}$ & Aceóca & Garganta \\
\hline Recape $^{130}$ & Racapé & Afrente em geral \\
\hline
\end{tabular}

de sopro, torto, encurvado; nos vocabulários do tupi da costa aparece a forma memby, evidente alteração de mimby. A pronúncia dessa palavra, vulgar no Brasil, parece-nos errônea. Os franceses escrevendo inubia indicavam claramente a pronúncia inybiá e não inúbia ou janúbia. Gonçalves Dias (Poesias Americanas, ed. Garnier, t. II, 113) fala em cantos da janúbia...'). Esses indivíduos tocam no meio das tropas ...”.

Cunha (1978: 155) comentou que "Embora já documentada no séc. XVIII [1781] com a acepção de 'corneta usada dos brasilienses', a palavra inúbia não parece de origem tupi"; cita alguns autores que usaram esse vocábulo: Durão (Caramuru, 1781), José de Alencar, Bernardo Guimarães, Coelho Neto, Lima Barreto e Monteiro Lobato. Cunha assinalou que José de Alencar, em Iracema, havia citado Léry, mas não foi buscar o trecho no livro do francês. Segundo Barbosa Rodrigues (1881: 36):

"O principal instrumento de guerra é o mymby-tareré dos tupys, que, segundo a tribo, toma diferentes nomes pelos seus dialectos. É a janubia de Gonçalves Dias, a inubya de Léry. Este, não compreendendo o valor das letras, escreveu mal, e aquelle, lendo errado a palavra, formou outra. Gonçalves Dias leu a palavra de Léry com o $y$ breve, e fez janubia, quando é mymby com y longo". Gonçalves Dias (1851: 7) grafou janubia:

\section{"E a caça leda e rápida \\ Por serras, por devesas, \\ E os cantos da janubia \\ Junto às lenhas accesas, \\ Quando o tapuya misero \\ Seos feitos vai cantar".}

E à página 290 o poeta acrescentou esta nota: "Janubia - Léry escreve diversamente: - des cornets, qu'ils nomment inubia de la grossuer [sic] et longueur d'une demie pique, mais par le bout d'embas d'environ un demi pied comme un hautbois. - Obra cit. Pág. 202".

O mesmo autor (Gonçalves Dias 1867:182; 1909:190-191), grafou tanto janubia quanto inubia, ao tratar dos instrumentos musicais dos tupis: "Por instrumentos tinham o maracá ou o fructo da coloquintida cheio de buzios, conchas, ou pedrinhas, com um hastil, ornado de plumas: tinham flautas feitas de ossos de finados, a que o padre Vasconcellos chama cangoera, e Morisot, o annotador de Roulox Baro 'Tibiae canguaca'; outras flautas feitas de conchas membi, as maiores, membi guassú; as de canna, membi apara; urucá feita de certa concha; o muremuré, assim chamado pelo som que soltava; o boré, feito de páo oco; a janubia ou inúbia, que era a sua trompa de guerra...". Seja qual for a origem de inúbia, Léry foi o único autor a citar originalmente o vocábulo, copiado depois por Dudley.

${ }^{128}$ Léry (1578: 375): “Ta-iout. Que ie vienne. Mais pour mieux emplir la significatiõ on adiouste ce mot Nein, qui est vn Aduerbe pour exhorter, commander, inciter ou deprier [nossa ênfase]”. Rodrigues (2009: 247): “ne'í, vamos!".

${ }^{129}$ Léry (1578: 365): “Ché-asseoc. Mon gosier”. Rodrigues (2009: 260): “ace’óca, minha goela".

${ }^{130}$ Léry (1578: 365): “Ché-rocapè. Mon deuant generalemẽt”. Rodrigues (2009: 260): “aé racapé, minha frente em geral". 


\begin{tabular}{|c|c|c|}
\hline Rousboni $^{131}$ & Rumbý & Lombo \\
\hline Reuire $^{132}$ & Rebíra & Nádegas \\
\hline Inuan poni $^{133}$ & Jybáypý & Espáduas \\
\hline Inua $^{134}$ & Jybá & Braço \\
\hline Po $^{135}$ & Pó & Mão \\
\hline Ponea $^{136}$ & Puã & Dedo da mão \\
\hline Puyac $^{137}$ & Pyá & Estômago \\
\hline Poron asseu $^{138}$ & Puruã & Umbigo \\
\hline Cam $^{139}$ & Cama & Peito de mulher \\
\hline Roduponam $^{140}$ & Rendypyã & Joelho \\
\hline Pouy $^{141}$ & Pý & Pé \\
\hline Pussempi $^{142}$ & Pyãpé & Unhas do pé \\
\hline Ponempe $^{143}$ & Puãpé & Unhas da mão \\
\hline Gugeney $^{144}$ & Nhyã & Coração \\
\hline
\end{tabular}

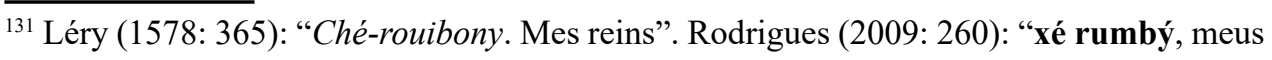
rins".

${ }^{132}$ Léry (1578: 365): “Ché-reuirè. Mes fesses”. Rodrigues (2009: 261): “xé rebíra, minhas nádegas".

${ }^{133}$ Léry (1578: 365): “Ché-inuanpony. Mes espaules”. Rodrigues (2009: 261): “xé jybáypý, minhas espáduas".

${ }^{134}$ Léry (1578: 365): “Ché-inua. Mes bras”. Rodrigues (2009: 261): “xé jybá, meus braços”. ${ }^{135}$ Léry (1578: 365): “Ché-po. Rodrigues (2009: 261): “xé pó, minha mão”.

${ }^{136}$ Léry (1578: 365): “Ché-poneu. Mes doigts” (1594: 289). Rodrigues (2009: 261): “xé puã, meus dedos".

${ }^{137}$ Léry (1578: 365): “Ché'puyac. Mon estomac ou foye”. Rodrigues (2009: 261): “xé py’á, meu estômago ou fígado".

138 Léry (1578: 365): “Ché-pourou-assen. Mon nombril”. Rodrigues (2009:261): "puru’ãçáma, meu umbigo (meu cordão umbilical)".

${ }^{139}$ Léry (1578: 365): “Ché-cam. Mes mamelles”. Rodrigues (2009: 261): "xé cama, meus seios". ${ }^{140}$ Léry (1578: 365): “Ché-roduponam. Mes genoux”. Rodrigues (2009:261): “xé rendypyã, meus joelhos".

${ }^{141}$ Léry (1578: 365): “Ché-pouy. Mes pieds”. Rodrigues (2009: 261): “xé pỹ, meus pés”.

${ }^{142}$ Léry (1578: 365): “Ché pussempé. Les ongles de mes pieds”. Rodrigues (2009: 261): “xé pyçãpé, as unhas de meus pés".

${ }^{143}$ Léry (1578: 366): “Che-ponampe. Les ongles de ma main”. Rodrigues (2009: 261): “xé puãpé, as unhas de minhas mãos”.

${ }^{144}$ Léry (1578: 366): Che-guy-encg. Mon Coeur \& poulmon”. Rodrigues (2009: 261): “xé nhy'ã, meu coração e pulmão". 


\begin{tabular}{|c|c|c|}
\hline Eney $^{145}$ & Anga & Alma \\
\hline Recouen $^{146}$ & Racuãnh(a) & Membro viril \\
\hline Aignen $^{147}$ & Anháng(a) & Demônio \\
\hline
\end{tabular}

${ }^{145}$ Léry (1578: 366): "Che-encg. Mon ame, ou ma pensee”. Rodrigues (2009: 261): "xé ánga, minha alma ou meu pensamento".

${ }^{146}$ Léry (1578: 366): "Che-rencouem" [Um dos "Noms des parties du corps qui ne sont honnestes à nommer']. Rodrigues (2009: 261): "xé racuãnha, meu pênis".

${ }^{147}$ Léry (1578: 233): "Et de fait ie croy que s'ils voyoyẽt vn de nos Gẽdarmes bien monte $\&$ arme auec la pistole au poing faisant bondir \& passader son cheual, qu'en voyant sortir le feu d'vn costé \& la furie de l'homme \& du cheual de l'autre, de prime face ils pẽseroyent que ce fut Aygnan, cest à dire le diable em leur langage"; Léry (1578: 262-264) "Toutefois pour commencer à declarer ce qui leur reste de lumiere, ie diray en premier lieu: qu'au milieu de ces espesses tenebres d'ignorãce ou ils sont detenus, que non seulemẽt ils croyẽt l'immortalité des ames, mais aussi ils tiẽnent fermement qu'apres la mort des corps celles de ceux qui ont vertueusement vescu, cest à dire selon eux qui se sont bien vengez \& ont beaucoup mangez de leurs ennemis, s'en vont derriere les hautes montagnes ou elles dansent dãs de beaux iardins auec celles de leurs grands Peres (ce sont les champs Elisiens des Poetes) \& au contraire que celles des effeminez \& gens de neant qui n'ont tenu conte de defendre la patrie vont auec Aygnan, ainsi nomment ils le diable en leur langage, ou elles sont incessament tormentees. Surquoy ie diray que ces poures gens durant leurs vies sont aussi tellement affligez de ce malin esprit (lequel autrement ils nomment Kaagerra) que comme i'ay vue par plusieurs fois, mesmes ainsi qu'ils parloyẽt à nous, se sentans tormentez, \& crians tout soudain comme enragez, nous disoyent helas defendez nous d'Aygnan qui nos bat: voire disoyent que visiblement ils le voyoyent tantost en guise de beste, d'oyseaux, ou d'autres formes estranges. Et parce qu'ils s'esmerueilloyent bien fort de voir que nous n'en estions point assaillis, quand nous leur disions que telle excẽption venoit de Dieu duquel nous leur parliõs si souuent lequel estãt sãs cõparaisõ pl. ${ }^{\circ}$ fort qu' Aignã gardoit qu'il ne ne nous pouuoit ni molester ni mal faire, il est aduenu quelque fois qu'eux se voyans pressez promettoyent d'y croire comme nous: mais suyuant le prouerbe qui dit, que le danger passe on se moque du saint, si tost qu'ils estoyent deliurez, ils ne se soucioyent plus de leurs promesses. Toutfois, pour monstrer que ce n'est pas ieu, ie leur ay véu souuent tellement apprehender cette furie infernale, que quand ils se ressouuenoyent de ce qu'ils auoyent enduré par le passe frappans des mains sur leurs cuisses, voire de destresse ayans la sueur au front, em se cõplaignans à moy ou à autre de nostre cõpagnie, ils disoyẽt. Mair Atouassap. Acequeiey Aygnan atoupaué, c'est à dire François mõ ami, ou mõ parfait allié, ie crain le diable, ou l'esprit malin, que toute autre chose. Que si au contraire celuy auquel ils s'adressoyent leur disoit. Nacecqueiey Aygnan, c'est à dire ie ne le crain point moy: en desplorant leur condition ils respondoyent: helas que nous serions heureux si nous estions comme vous autres. Il faudroit croire $\&$ nous vous assurer comme nous faisons en celuy qui est plus puissant queluy, repliquions nous: mais comme i'ay dit quelques protestations qu'ils fissent d'ainsi le faire, tout cela s'esuanoissoit incontinent deleur cerueau"; Léry (1578: 338) "dés la premiere nuit d'apres qu'vn corps, à la façon que vous auez entendu, a esté enterré, eux croyans fermemẽt que si Aygnan, c'est à dire le diable em leur lãgue ne trouoit d'autres viandes toutes prestes aupres, qu'il le deteereroit \& mangeroit, nõ seulement ils mettent de grands plats de terre pleins de farines, volailles, poissons \& autres viandes bien 


\section{Agradecimentos}

À Profa. Dra. Cândida Barros (Museu Paraense Emílio Goeldi), por críticas e sugestões. Ao CNPq pelo apoio que vem prestando às pesquisas do autor sênior nos últimos anos.

Figura 18 - Frontispício do segundo volume do Arcano del Mare (2 ${ }^{\text {a }}$ edição) de Dudley (1661)

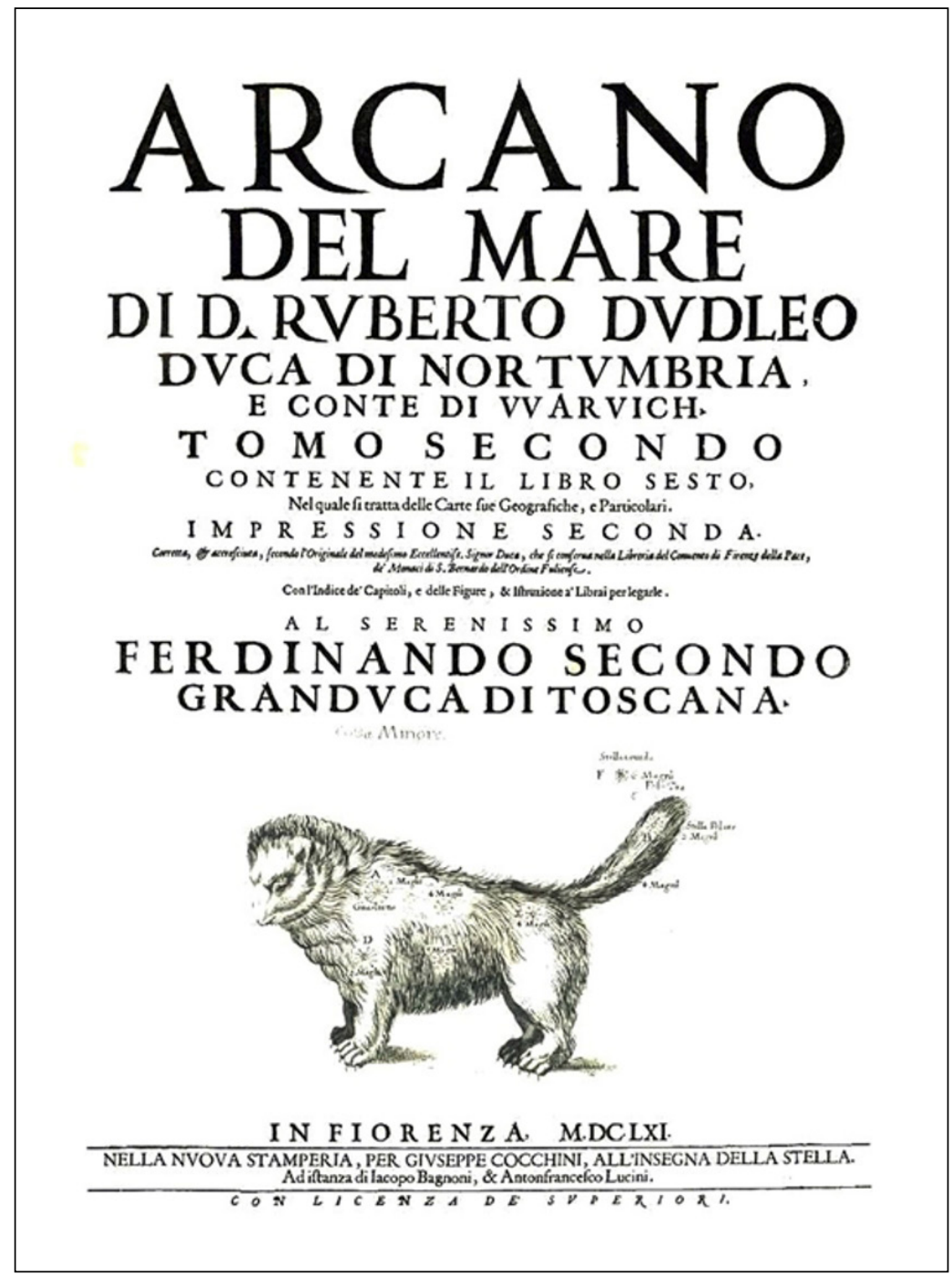

cuités auec de leur breuuage dit Caouin sus la fosse du defũct, mais aussi isqu'à ce qu'ils pensent que le corps soit entierement pourri, ils continuent à faire tels seruices, vrayement diaboliques". 
Figura 19 - Vocabulário tupinambá (Dudley, 1661: 34)

\author{
L I B R O S E S T O.
}

torio pià eminete della Brafiglia, il quale tutti inauiganti in quelle particereano di vodere; \& apparifce, per conera.

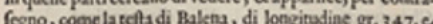
heriudine gr. $8 . \mathrm{e} \mathrm{min}$. 44 . Auftrale: Vicino à quefto verfo

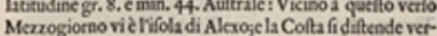
fo Meraogionn Libeccio, con parecchi fumi noeati nella Carta, che terminis con il capo, f fume Avoredss, di los. gitudine gr. 355. emin. 46 . elatitudine gr. $10 . \mathrm{e}$ mez. Al firale.

Fernambech fu gia nominato Olindo dal fiums,e golfo deflifteflo nome : I venti lingo alla Cofta, doppo Orobre fono Grecali, e Leuanti, edoppo Marzo foeo Scirocchise di rado in qued mare fit trounoo iventi Macftrali, La Cofta è pians, e piena di bofkhi, efiumi fia'al rio sant'Antonios ma le genti fono Canibi, e cattiue : L'́lóte, efcogli fi ve\%"

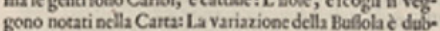
biofa per noa effere tata ben'ofleruata da' Marinari dotti, \& intelligenti.

DELL AMERICA, E DICHIARAZIONE

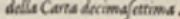
Cą.XXXVIIII.

c.p.ter

COmincia quetta Cara col capo , e fume sant'Antonio di longitudine gr. $356 . \mathrm{clat}$ titudine gr, $10, \mathrm{e}$ tercipale destla, c porto dello Spirito santo, laogo prinno, legno sunto, ed altre mercanaie del puefe, dilonein. ding Sulason, fra effa, ela panta, che è nomiminata Tubcron, il foedo farà tra pafí s.e 8. Evenendo da Tramontana, per trouare il detto Porto di Spirito sunto, bifogna allargarfi in Mare più leghe, per isfoggire le fecche delila Colta, $c$ las Baixas di Abrollas, che li vede per la Carta; fe bene per ef fa Cofta fi troea prima il porto di Todos Sandos citta me tropoli della Brafiglia, nella quale vi fi contiene mille crfe, c40. ingegni da zuchero; ma Fernambuch cे citta mag giore, e peà ricca. Poi verfo Mezzogiorno Libeccio di Todos Siatos fi trousa il porto das IIsas, il qual'e beon Porto , ma l'entratura è pericolofa per gli fcogli, e feccagac, che vifono, fenza va buon Piloto: Cocticne is o,cafe, etre ingegni da zucchero: Poi verfo Mezzogiono v'c al porto Sicuro, il quale gid conteneua trecento cafe in tre villaggi, sc apparticne alli signori Giraldi di Lisoona parenti dé stgnori Giraldi di Firenze ; e nell' cntrare nel porto dello Spi. rito saeto, búlogna gardarfi da va fecca, chec̀ nel mez. zo della bocca ; scil contrafigno per conoficere il Porto cे la vedata del monte d'Aluares; $\$$ in bifogno fi paò dar fondo per naüi, e con beon riparo, forto lifola Salauron, in palt 5. di fondo, coned di fopra c auacrtito.

Nellientrare del fuddetto porto Sicuro, bifogna guandarf dalla feccagna di Paraguama, che, perciò fare, biflogna,per contrafcgno, gandare verfo il mocte Pafcolo : II Cafteflo calto ; edentro al Porto vi è buono ftare per navi grofic.

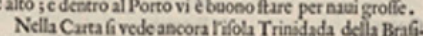
glia, doue vic boona spiaggia per la parte di Mezuogiorno

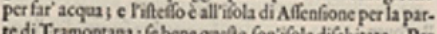
te di Tramontana ; fe bene gacte fon'ífole difabitate. Per l'altre offerumioni della variazione della Beffola, della corrente, ede' venti, fi rifcrifce alla Carta.

DELL AMERICA, E DICHIARAZIONE della Corts decimatrous S. I.

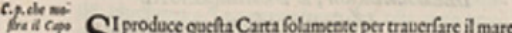

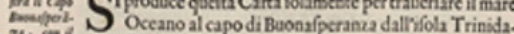

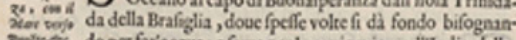
do per far'acqua ; e ferue per la nauigaxione all'Indic dalle cofta di Brafiglia, mediante la Carta precedente. L'altre Ifole per la via, l'offeruarioni de' venei, fellie correat i,e Panteleats, America.
A principalmente della variazione grande della Buffata nel

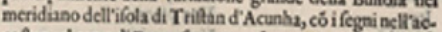
coftare al capo di Baonafpriamz, fono notati nella Carté, eperò noa occorte allungarficoa la dichiarzione: A Auer? tendo, che fi paffi mieglio il detto Capo nel mefe d'A a gofto, eprincipio dieffo;per arriazre poi a Goa,pell'Indie,ne'mefí dOtrobre, edi Noutmbre.

DELLAMERICA, E DICHIARAZIONE della Certa dromawe, 5. 2 .

$Q^{\mathrm{r}}$

Ala Carta comincia con fífola Salaron, quafi ncl- c.pe.eftec

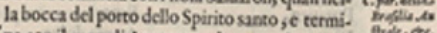

B vefo Trabeana capo di Ararunga, done per la parte vero Tramontana cntra il rio santa Maria: La lonb gitudine del capo cे gr. 339. e latitudine cे gr. 3 r.fe bene la Cota c̀ abitata folamente da' Portughefi fin'alla città porto difan Vincenzio, ò Vincente vicino à Samosic econ tiene quattrocento cafe, con tre ingegni da zucchero : II Porto c buono, \& anco vi c commcrio, di longitudine gr. 343. elatitudine gr. 24. Auftrale.

Doppo lo Spirito santo, per la Colta, fitrous da vicino rifola santa Chiara, doue fra goefta, ela terra ferma vi è beoniffimo riparo per naui grotlc, e per far'acqua, in di latitudine, $\partial$ in cirea ; \& in or, $2, \mathrm{cmez}$ di latindine Auftrakentra la baia dissa S1lasdore, dieci leghe loatsno dalcspo Frio, il quale d li proanontorio più eminente della Beafiglia Auftrale; e tredici leghe per Ponéte Jel detto Ca.

C po, vi entra il fame, e porto di Genero laogo di conimerzio, Il quale contiene trecento cafe, edue ingegai ds ase chero, \& asco vic̀ affai legno verzino .

Per Ponente del fiume Genero, che già era de' Fraritét fi vede lífola di Pla cenzia difabitats; ma in mare viè booon riparo ernasui, eper far'acqua, nellifíla; \&il molcGmo fi poò fure allififola sua Sebaftiano, ciod tra effs, ela terra fcrma; \& a aco viè buoa porto in noas, e dieci palfidifon. do, e vifitrom ancora dellicous buon. Poi con bon di Alcatraces, chè terra alta, vi catra la baia di Sances, 8 . il porto di san Vincente di fopea sominato; $\mathrm{e}$ quiui finifce l'abitazione de' Portughefi nella Brafiglia Auftrale: Nelle bain di Oacrniron vi c riparo per naui, in gr. 28. di latita. dine, \& anco vifi pod far'acqua : Paffato oucta Bria five

D de fubito lifola luaga di sunta Caterina; $\$$ addirimpetto nella terra ferma vicil porto di Patas, ò Catas, perfar'ac* qua , ma noa è loogo di commerzio, effendo quetto in gr. 29. dilatitudine Auftrale : Enclla latitudine digr. 30. per L Colta fi troua il porto di Laguas, doue vi c̀ boon porto per naui, mediante Kífla di Riparas \& anco vic̀ da pigfia. redell'sçu, \& altri rinfrefcumenti: Dells vie da piglia. lamitica, per la colta di Brafiglia, non vi è certezus; e però il pià ficuro furd d'offeruarla efattamente, per fuggire la va-
ricta dell'opinioni. Il porto di Rodorigo ed di latitudine gr. ricti dell'opinioni. Il porto di Rodorigo edi latitudine gr. 29. $\mathrm{cmin} .42 .8$
dLeuante.

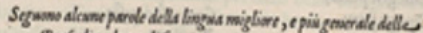

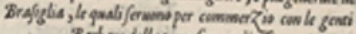

$$
\text { Babler dills tors forme di jols. }
$$

Erimen; vutlire Noaso.

Tourofloagates, Principulinente.

Ioh, Sonopronto.

Ercendoup, Ho fentito.

Mahmo, Molti.

Rothoenagum; Vavillaggio.

Augepe, Vacola.

Toiocru, Vool pio

Araip,

Cositita.

Oicotgato, $\quad$ Elontano digal.

S Verap, 
Figura 20 - Vocabulário Tupinambá (Dudley, 1661: 36)

$x 2$

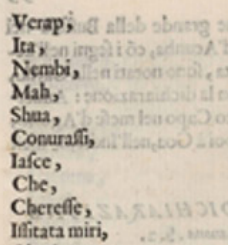

Iflitata miri,

Chetin,

Poury,

Vhete,

Vheen,

Augebo,

Agne be oach,

Stipoque,

Manuo amo pe?

Maeds,

Setaque,

Cembere ingue,

Arousn,

Kuap,

Soo,

Oura,

Pira,

Ouy,

Pinda,

Arrout,

Guia par ete,

Marause,

Auge gaton tega,

Setape,

Necri,

Aaubs,

Mabouy,

Augebe,

Auc,

Vous,

Iuron,

Redmi va aue,

Apelou,

Ram,

Che aiozue,

Poca,

De,

Alie,
Orece,

Pee,

Ause,

Emiredutata,

Emegosptata,

Emogipera,

Eficlla,

Coceri vpe,

Erotvichelai,

Cherenue augepe

Querema shęemyourecos

Tace poch,

Che embouafi,

Cherace,

Cheracoup,

Checaroe,

Caroue,

Cherocmp,

Chere,

\section{DELL'ARCANO DEL MARE}

Iltempo c̀ ofcuro.

Var pietra.

Vn'orecchio.

IICiclo,

L. fronte.

La Luna.

b.

Glioxchi.

Leftelle del Cielo

In nafo.

Laterra.

Il mare.

Acqua dolce.

L'acquadel mare.

Soncerto.

Quel che dicosè vero.

Noa parlo fenza occafione.

Perche lo domandate ?

L. a firmma del fuoco.

Cifonomolti.

Afpettate quil.

Vno fpecchio.

Vapettine.

Beftiame faluztico.

Glivecelli.

Pefee.

Farina.

Lamoda pefcare.

Vn punteruolo.

Gli bo dato.

Sono cofe grandi.

Da quel,chio fono.

Egli ha difcorfo molto bene.

Dimolti.

Orsu.

Veftiti.

Quanti fiate.

Eben detto .

Il capo.

La ficcis.

Il frasellominore.

Labocas.

Labarba.

Lalingua.

I denti.

Il collo.

In petto.

Tu.

Foli,jolui.

Noi.

Voi.

Quelli.

Andate fuori.

Glie fegno del fuoco.

Certecoledipofice.

Toglicte.

Val bere alla fonte.

Datemi dell' acqua.

Datenui bere.

Datemi mapgiare.

Io ho fete.

Io findo.

Sono freddo.

Io ho la febbre.

Ne hò dolore.

La notte, od fera.

Ne fon'allegro.

Vaferuitore.

A Qucre maliau, Cherop,

Cherequeat,

Renudire,

Tacout,

Tipet,

Aica,

Cbesí,

Sat,

Cheraijt,

Ramemynoen,

Aico,

Ereno,

Oico,

B Oreico,

Peico,

Auree aico,

Aico ay aquecente

Acoire,

Tauge,

Taicodei ron,

Aiour,

Ereioat,

Ooat,

Oreiour,

Andeoout, Aiout agoueme,

Aiout irun,

C Emoout,

Peori,

Aiout mo,

Enegouere,

Ranggere,

Tavvme,

Inubya,

Neui,

Afcoc,

Recape,

Rousboni,

Reuire,

D Inuan poni,

Inua,

Po,

Pones,

Puyac,

Poroa affer,

Can,

Roduponam,

Pouy,

Puffempi,

Ponempe,

Gugeney,

Ency,

E Recouen,

Aignen,

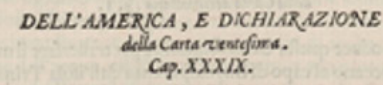

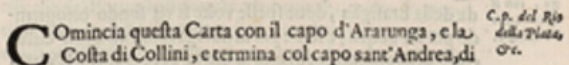
longitudine gr. 325 . e Latit. gr. 39. cmin. 14. ia circs.
Epotente in guerrs.

Il padre.

Lagiore.

Vengo, dverrò

l.a figlia della forella.

Vn'amica.

L. a matrigna.

La figlia.

Il nipote del nonno.

Io fono

Voifiate.

Io fon qui.

Allora łarò.

Sono con voi.

lo vengo.

Egli venim.

Egli verra.

Quelli fono venuti.

Allora veniuano.

Vengano.

io poffa venire.

L'anima è vfita del corpo.

IIDemonio.

Egliverrì.

Vna cornetta ali efika a degl' in

dien.

Viprego.

La parte di dietro d'vn' huo

Iere

Le marici.

Lespalle.

Lebraccia.

Ledita.

Loftomaco.

Il bellico .

Lepopped'vna donna .

Le ginocchis.

L'vnghie delle dita de' piedi.

Lvinghie delle dita delle ma.

ni.

L'anima , e fpirito d'vn'huo.

Le membra fegreted'vn huo mo, d̀ d'vna Donna.

Vil Demonio perticelert, diefree

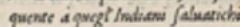
dilla brats sus. 


\section{Referências}

Adams, S. 2008a. Dudley, Sir Robert (1574-1649). Oxford Dictionary of National Biography. Oxford, Oxford University Press.

Adams, S. 2008b. Sheffield, Douglas, Lady Sheffield (1542/3-1608). Oxford Dictionary of National Biography. Oxford, Oxford University Press.

d'Angelo, M. 2004. Mercanti inglese a Livorno 1573-1737, Alle origini di una "British Factory". Messina, Istituto di Studi Storici Gaetano Salvemini.

Anônimo, 1829a.Travellers' tales. The New Monthly Magazine and Literary Journal 1829 (Part II.Original papers): 143-157, London [Menção a William Davies e ilha de Morria à p. 152].

Anônimo. 1829b. Tales of travellers. American Masonick Record and Albany Saturday Magazine. Being a periodical journal, devoted to masonry, arts and sciences, biography, sketches of character, manners and customs, popular tales, miscellany, poetry, literary and political news, \&c. \&c. 3 (4): 316-317, Albany. N. Y. [Menção a William Davies e ilha de Morria].

Barão do Rio Branco. 2012. Obras do Barão do Rio Branco IV. Questões de limites. Guiana Francesa. Segunda Memória. Brasília, D. F., Fundação Alexandre de Gusmão, Ministério das Relações Exteriores.

Barbosa Rodrigues, J. 1881. O canto e a dança selvícola. Revista Brasileira 9: 32-60, Rio de Janeiro.

Braudel, F. 1966. La Méditerranée et le monde méditerranéen a l'époque de Philippe II. Seconde édition revue et augmentée. Tome premier. Paris, Librairie Armand Colin.

Cunha, A. G. da. 1978. Dicionário histórico das palavras portuguesas de origem tupi. São Paulo, Edições Melhoramentos \& Instituto Nacional do Livro, Ministério da Educação e Cultura.

Davies, W. 1614. A true relation of the travailes and most miserable captiuitie of William Dauies, barber-surgion of London, vnder the Duke of Florence. VVherein is truly set downe the manner of his taking, the long time of his slauierie, and meanes of his deliuerie, after eight yeeres, and ten moneths captiuitie in the gallies. Discouering many mayne lands, ilandes, riuers, cities, and townes, of the Christians and infidels, the condition of the people, and the manner of their country: with many more strange things, as in the booke is briefely and plainely expressed. By William Dauies, barber-surgion of London, and borne in the citie of Hereford. London, Printed by [Thomas Snodham] for Nicholas Bourne.

Davies, W. 1625. A Description and discouery of the Riuer of Amazons, pp. 12871288, in PURCHAS, S., Pvrchas his Pilgrimes. In five bookes. The sixth, containing English voyages, to the east, west, and south parts of America: Many sea and land fights, inuasions and victories against the Spaniards in those parts, and the Spanish Ilands and coast towns on this side; plantations in Guiana, and many strange aduentures of English-men amongst the Americans. The seuenth, voyages to and about the Southerne America, with many marine obseruations and discoueries of 
those seas and lands, by English-men and others. The eighth, voyages and landtrauels in Florida, Virgina [sic], and other parts of the the Northerne America, French plantings, Spanish supplantings; English-Virginian voyages, and to the Ilands Azores. The ninth, English plantations, acts, and occurents, in Virginia and Summer Ilands, since the yeere 1606. till 1624. The tenth, English discoueries and plantations in New England, New-found-land; with the Patent and voyages to New Scotland; relations also of the fleets set forth by Queen Elizabeth against the Spaniards. The Fourth Part. London, Printed by William Stabsby, for Henrie Fetherstone.

Davies, W. 1745.A true relation of the travels and most miserable captivity of William Dauies, barber-surgion of London, under the Duke of Florence. Wherein is truly set down the manner of his taking, the long time of his slaverie, and means of his delivery, after eight years and ten months captivity in the gallies. Discovering many main lands, islands, rivers, cities, and towns, of the Christians and infidels, the condition of the people, and the manner of their country: with many more strange things, as in the book is briefly and plainly expressed, pp. 475-488, in OSBORNE, T.. A collection of voyages and travels, consisting of authentic writers in our own tongue, which have not before been collected in English, or have only been abridged in other collections. And continued with others of note, that have published histories, voyages, travels, journals of discoveries in other nations and languages, relating to any part of the continent of Asia, Africa, America, Europe, or the islands thereof, from the earliest account to the present time. Digested according to the parts of the world, to which they particularly relate: With historical introductions to each account, where thought necessary, containing either the lives of the authors, or what else could be discovered and was supposed capable of entertaining and informing the curious reader. And with great variety of cuts, prospects, ruins, maps, and charts. Compiled from the curious and valuable library of the late Earl of Oxford. Interspersed and illustrated with notes, containing either a general account of the discovery of those countries, or an abstract of their histories, government, trade, religion, \&c., collected from original papers, letters, charters, letters patents, acts of parliament, \&c., not to be met with, and proper to explain many obscure passages in other collections of this kind. Vol. I. London, Thomas Osborne.

Dudley, R. 1646-1648. Dell'Arcano del Mare di D. Ruberto Dudleo Dvca di Nortumbria e Conte de VVarwich libri sei; nel primo de'quali si tratta della longitudine praticabile in diversi modi, d'invenzione dell'autore. Nel secondo, delle carte sue generali, e de' portolani rettificati in longitudine, e latitudine. Nel terzo, della disciplina sua maritima, e militare. Nel quarto, dell'architettura sua nautica di vascelli da guerra. Nel quinto, della navigazione scientifica, e perfetta, ciò̀ spirale, ò di gran circoli. Nel sesto, delle carte sue geografiche, e particolari. Al Serenissimo Secondo Gran Duca di Toscana suo Signore. Firenze, Nella Stamperia di Francesco Onofri.

Dudley, R.. 1661. Arcano del Mare di D. Ruberto Dudleo Duca di Nortumbria, e Conte di Warvich : Tomo Secondo contenente il Libro Sesto, nel quale si tratta delle Carte sue Geografiche, e Particolari. Impressione Seconda. Corretta \& accresciuta, secondo l'originale del medesimo Eccellentiss. Signor Duca, con l'indice de' Capitoli, e delle figure, \& istruzione a'librai per legarle. Al Serenissimo 
Ferdinando Secondo Granduca di Toscana. Fiorenza, Nella Nuova Stamperia, per Giuseppe Cocchini. [Disponível na Biblioteca Digital Hispánica].

Dudley, R. 1904. A Voyage of the honourable Gentleman M. Robert Duddeley, now knight, to the isle of Trinidad, and the coast of Paria: with his returne home by the Isles of Granata, Santa Cruz, Sant Juan de Puerto rico, Mona, Zacheo, the shoals called Abreojos, and the isle of Bermuda. In which voyage he and his company tooke and sunke nine Spanish ships, whereof one was an armada of 600 tunnes. Written at the request of M. Richard Hakluyt, pp. 203-212, in HAKLUYT, R., The Principal navigations voyages traffiques \& discoveries of the English nation. Made by sea or over-land to the remote and farthest distant quarters of the Earth at any time within the compasse of these 1600 yeeres. Glasgow, James MacLehose and Sons \& New York, The Macmillan Company.

Edmundson, G. 1903. The Dutch on the Amazon and Negro in the seventeenth century. The English Historical Review 28 (72): 642-663, London.

Gonçalves Dias, A. 1851. Ultimos cantos. Poesias. Rio de Janeiro, Typographia de F. de Paula Brito.

Gonçalves Dias, A. 1909. Obras posthumas de A. Gonçalves Dias. O Brazil e a Oceania. Paris, H. Garnier, Livreiro-Editor.

Holanda, S. B. de. 1967. Os projetos de colonização e comércio toscanos no Brasil ao tempo do Grão-Duque Fernando I (1587-1609), pp. 147-170, in Paula, E. S. de, Colonização e migração. Trabalhos apresentados ao IV Simpósio dos Professôres Universitários de História (Pôrto-Alegre, 3 a 8 de setembro de 1967). São Paulo, Faculdade de Filosofia, Ciências e Letras, Universidade de São Paulo.

Holanda, S. B. de. 2000. Os projetos de colonização e comércio toscanos no Brasil ao tempo do Grão Duque Fernando I (1587-1609). Revista de História 96: 95-122, São Paulo.

Laet, J. de. 1633. Novus Orbis seu descriptionis Indiae occidentalis libri xviii. Authore Ioanne de Laet antverp. Novis tabulis geographicis et variis animantium, plantarum frctuumque iconibus illustravit. Lugdunum Batavorum [= Leiden], Elzevirios,.

Leader, J. T. 1895. Life of Sr Robert Dudley, Earl of Warwick and Duke of Northumberland. Illustrated with letters and documents from original sources, collected by the author, and hitherto inedited. Florence, G. Barbèra.

Lee, S. L. 1888. Davies, William (fl. 1598-1614), p. 161, in STEPHEN, L., ed..Dictionary of National Biography.Vol. XIV. Damon-D'Eyncourt. New York, Macmillan and Co. \& London, Smith, Elder, \& Co.

Léry, J. de. 1578. Histoire d'vn voyage fait en la terre dv Bresil, avtrement dite Amerique. Contenant la nauigation, \& choses remarquables, veuës sur mer par l'aucteur. Le comportement de Villegagnon, en ce païs là. Les meurs \& façons de viure estranges des Sauuages Ameriquains: auec un colloque de leur language. Ensemble la description de plusieurs Animaux, Arbres, Herbes, \& autres choses singulieres, \& du tout inconnues par deça, dont on verra les sommaires des chapitres au commencement du liure. Non encores mis en lumiere, pour les causes contenues 
en la preface. Le tout recueillis sur les lieux par Iean de Léry natif de la Margelle, terre de sainct Sene au Duché de Bourgogne. La Rochelle, Antoyne Chuppin.

Léry, J. de. 1594. Historia navigationis in Brasiliam qvae et America dicitvr. Qva describitvr avthoris nauigatio, quaéque in mare vidit memoriae prodenda: Villegagnonis in America gesta: Brasiliensium victus \& mores, à nostris admodum alieni. Cum eorum linguae dialogo: animalia etiam, arbores, atque herbae, reliquáque singularia \& nobis penitus incognita. A Johanne Lerio bvrgvndo gallicè scripta. Nunc verò primùm latinitate donata, \& varijs figuris illustrata. Secvnda editio. Genevae, Apud haeredes Eustathij Vignon.

Léry, J. de. 1980. Viagem à terra do Brasil. Tradução e notas Sérgio Milliet. Bibliografia Paul Gaffarel. Colóquio na língua brasílica e notas tupinológicas Plínio Ayrosa. Belo Horizonte, Editora Itatiaia Limitada \& Editora da Universidade de São Paulo.

Léry, J. de. 2009. História de uma viagem feita à Terra do Brasil, também chamada América. Apresentação da coleção Fundação Darcy Ribeiro. Introdução geral Carlos de Araujo Moreira Neto. Introdução do volume Carlos de Araujo Monteiro Neto. Contribuição lingüística, restauração dos vocábulos em língua Tupi e tradução do Capitulo XX Aryon Dall'Igna Rodrigues. Tradução Maria Ignez Duque Estrada. Revisão da tradução Gisele Jacon. Rio de Janeiro, Fundação Darcy Ribeiro.

Neri, A., 2000. Uno schiavo inglese nella Livorno dei Medici. Pisa, Edizioni ETS.

Papavero, N., D. M. Teixeira, W. L. Overal \& J. R. Pujol-Luz. 2002. O novo Éden. A fauna da Amazônia brasileira nos relatos de viajantes e cronistas desde a descoberta do rio Amazonas por Pinzón (1500) até o Tratado de Santo Ildefonso (1777), com transcrição dos principais textos. $2^{a}$. edição, revista e ampliada. Belém, Museu Paraense Emílio Goeldi.

Payne, J. T. \& H. Foss. 1842. Bibliotheca Grenvilliana; or Biographical notices of rare and curious books, forming part of the library of the Right Hon. Thomas Grenville. Vol. I. London, William Nicol.

Penard, T. E. 1928. Remarks on an old vocabulary from Trinidad. Nieuwe West-Indische Gids/ New West Indian Guide 9: 265-270, Leiden.

Porro, A. 1993. As crônicas do rio Amazonas. Tradução, introdução e notas etnohistóricas sobre as antigas populações indígenas da Amazônia. Petrópolis, RJ, Editora Vozes.

Purchas, S. 1906a. A description and discovery of the River of Amazons, by William Davies Barber Surgeon of London, pp. 423-416, in seu Hakluytus posthumus or Purchas his Pilgrimes containing a history of the world in sea voyages and lande travels by Englishmen and others. Volume XVI. Glasgow, James MacLehose and Sons.

Purchas, S. 1906b. The relation of Master John Wilson of Wansted in Essex, one of the last ten that returned into England from Wiapoco in Guiana 1606, pp. 338-351, in seu Hakluytus posthumus or Purchas his Pilgrimes containing a history of the world in sea voyages and lande travels by Englishmen and others. Volume XVI. Glasgow, James MacLehose and Sons. 
Raleigh, W. 1596. The discoverie of the large, rich and bewtifvl Empyre of Gviana, with a relation of the great and Golden Citie of Manoa (which the Spanyards call El Dorado) and of the Prouinces of Emeria, Arromaia, Amapaia, and other Countries, with their riuers, adioyning. Performed in the yeare 1595. by Sir W. Ralegh Knight, Captaine of her Majesties Guard, Lo. Warden of the Scanneries, and her Highnesse Lieutenant general of the Countie of Cornewall. London, Robert Robinson.

Ridolfi, R. 1962. Pensieri medicei di colonizzare il Brasile. Il Veltro, Rivista della Civiltà Italiana $6: 1-18$, Roma.

Rodrigues, A. D., 2009. Capítulo XX. Colóquio entre as gentes do país, pp. 245-268, in LÉRY, 2009, q. v.

Role, R.. 2003. Sir Robert Dudley Duke of Northumberland. History Today 53 (3): 3137, London.

Sanfilippo, M., 2008. Gli Italiani in Brasile. Viterbo, Edizioni Sette Città.

Schomburgk, R. H., ed. 1848. The discovery of the large, and beautiful Empire of Guiana, with a relation of the great and golden city of Manoa (which the Spaniards call El Dorado), etc. Performed in the year 1595, by Sir W. Ralegh, Knt., Captain of Her Majesty's Guard, Lord Warden of the Stannaries, and Her Highness's Lieutenant-General of the County of Cornwall. Reprinted from the edition of 1596, with some unpublished documents relative to that country. Edited, with copious explanation notes and a biographical memoir, by Sir Robert H. Schomburgk, Ph. D., Knight of the Royal Prussian Order of the Red Eagle, of the Royal Saxon Order of Merit, of the French Order of the Legion of Honours, etc. London, Hakluyt Society.

Silva, A. P. da. 2011. Narradores Tupinambá e etnosaberes nas crônicas francesas do Rio de Janeiro (1555-1578) e do Maranhão (1612-15). Dissertação de Mestrado, Programa de Pós-Graduação em Memória Social, Linha de Pesquisa Memória e Patrimônio, Centro de Ciências Humanas, Universidade Federal do Estado do Rio de Janeiro, Rio de Janeiro, RJ.

Smedley, E., H. J. Rose \& H. J. Rose. 1845. Encyclopaedia metropolitana; or, Universal dictionary of knowledge, on an original plan: Comprising the twofold advantage of a philosophical and an alphabetical arrangement, with appropriate engravings. Volume XIX. [Miscellaneous and lexicographical, Vol. 6]. Cambridge, R. Fellowes; F. and J. Rivington; Duncan and Malcolm; Suttaby and Co., E. Hodgson; J. Dowding; G. Lawford; J. M. Richardson; J. Bohn; T. Allman; J. Bain; S. Hodgson; F. C. Westley; L. A. Lewis; T.Hodges; and H. Washbourne, London; J. H. Parker and T. Laycock, Oxford; J. and J. J. Deighton. [P. 445: William Davies, no artigo Galleys].

Vaughan, T. 1858. The Italian biography of Sir Robert Dudley, Knt. Known in Florentine History as il Duca di Nortombria, under the diploma of Ferdinand II. Emperor of Germany, dated March 9, 1620. To which are added, some biographical notices of Dame Alice Dudley his wife, created Duchess Dudley by Charles I, May 23, 1645. As also of their four daughters Alicia Douglassa, Frances, Anne, and Catharine. Oxford, Baxter. 
Villani, S. 2003. Una piccolo epitome di Inghilterra. La comunità inglese di Livorno negli anni di Ferdinando II: Questioni religiose e politiche. Firenze, Cromohs [Cyber Review of Modern Historiography] 8: 1-23.

Wadsworth, J. 1630. The English Spanish Pilgrime: Or a New Discovery of Spanish Popery and Jesuitic stratagems. London.

Warner, G. F., ed. 1899. The voyage of Robert Dudley, afterwards styled Earl of Warwick and Leicester and Duke of Northumberland, to the West Indies, 15941595, narrated by Capt. Wyatt, by himself, and by Abram Kendall, Master. London, Hakluyt Society.

Wilson, D. 1981. Sweet Robin: A Biography of Robert Dudley Earl of Leicester, 15331538. London, Hamish Hamilton.

Zeron, C. A. de M. R. \& C. Z. Camenietzki. 1967. Nas sendas de Sérgio Buarque de Holanda. Documentos sobre uma expedição florentina à Amazônia, em 1608. Revista de História 71: 61-84, São Paulo.

Data recebimento: $10 / 01 / 2015$

Data aceite: $10 / 04 / 2015$ 